Teka Kom. Hist. OL PAN-TN KUL, 2020, 2(17), 103-134

DOI: http://dx.doi.org/10.18290/teka.20.6

\title{
GÓRNY ŚLĄSK A WOJNA POLSKO-BOLSZEWICKA NA ŁAMACH „GWIAZDKI CIESZYŃSKIEJ”

\author{
RELACJE I KOMENTARZE
}

\author{
Zdzisław Janeczek \\ Uniwersytet Ekonomiczny w Katowicach \\ University of Economics in Katowice \\ e-mail: ujnefretete@vp.pl
}

Streszczenie. Autor na podstawie kwerendy prasy, głównie „Gwiazdki Cieszyńskiej” z lat 1920-1921, zaprezentował zależności, jakie łączyły Górny Śląsk i Rzeczpospolitą w okresie wojny polsko-bolszewickiej, a w szczególności latem 1920 r., gdy rozegrała się bitwa warszawska. Pokłosiem „cudu nad Wisłą” był „cud nad Odrą”.

Powodzenie militarne bitwy warszawskiej i trzeciego powstania śląskiego skutkowało włączeniem w granice II Rzeczypospolitej wschodniej części Górnego Śląska, która była drugim zagłębiem przemysłowym Europy. Wydarzenie to zmieniło w znaczący sposób strukturę gospodarczą rolniczej Polski, upodobniając stosunki polskie do krajów o kulturze kapitalistycznej. Przyłączenie części tej historycznej prowincji, którą Jan Długosz zaliczał do części „ciała Korony Polskiej”, ze względu na wielkość potencjału przemysłowego i wojskowego tego obszaru było dużym wydarzeniem nie tylko politycznym, ale i gospodarczym, a także wojskowym. Górny Śląsk był największym okręgiem przemysłowym w kraju. Fakt ten podkreślała „Gwiazdka Cieszyńska” w artykule O znaczeniu Górnego Śląska opublikowanym w numerze 215 z 1920 r.

Słowa kluczowe: powstania śląskie; wojna polsko-bolszewicka; „Warschau gefallen”; „cud nad Wisłą”; „cud nad Odrą”; plebiscyt; Górny Śląsk; traktat wersalski; appeasement; Sicherheitswehr; POW G.Śl.

\section{WSTĘP}

„Gwiazdka Cieszyńska” była wydawana w Cieszynie w latach 1851-1939 jako kontynuacja „Tygodnika Cieszyńskiego” (1848-1851). 1 marca 1851 r. pismo zmieniło nazwę z „Tygodnika Cieszyńskiego” na „Gwiazdkę Cieszyńską Pismo Naukowe i Zabawne”, a od 1 I 1852 r. używało tytułu: „Pismo dla Nauki, Umiejętności, Zabawy 
i Przemysłu". Jego redaktorzy akcentowali polskość Śląska oraz dbali o krzewienie oświaty wśród mieszkańców Śląska Cieszyńskiego. Chętnie nawiązywali do „marzeń" kronikarza Jana Długosza (1415-1480), by Śląsk wrócił do Polski ${ }^{1}$. Redaktor Paweł Stalmach (1824-1891) na kongresie słowiańskim w Pradze nalegał na połączenie Śląska Cieszyńskiego z Galicją, a Górnego i Dolnego Śląska (który pozostawał wówczas pod władzą Prus) - z Wielkopolską. Za swoją działalność społeczną oraz antyrządowe artykuły był kilkukrotnie więziony oraz karany grzywnami²

W piśmie unikano radykalnych socjalistycznych haseł, a nawet były one przedmiotem uwag krytycznych. Żywotnie jednak redakcja była zainteresowana sprawami polskimi i stosunkiem mocarstw do kwestii niepodległości, a także zbieżnościami i różnicami w tej materii między nimi. W monarchii Habsburgów, w dobie konserwatywno-centralistycznych rządów premiera Aleksandra von Bacha, zwolennika polityki germanizacyjnej, w latach 1852-1859 „Gwiazdka” była jedyną polską gazetą na Śląsku Cieszyńskim. W latach 60. XIX w. miała około 1400 subskrybentów, z czego 300 na Śląsku a 600 w Galicji. W 1907 r. jej nakład wynosił ponad 4,6 tys. egzemplarzy. Była pismem oczekiwanym i poszukiwanym. Treść w dużej mierze dotyczyła współczesnych wydarzeń historycznych. Należała do grona gazet, które informowały i wyrażały opinię oraz miały swoją ciągłość tematyczną. Pod względem szaty graficznej i formatu, układu wzorowana była na podobnych pismach kolportowanych na obszarze monarchii Habsburgów.

W 1883 r. „Gwiazdka Cieszyńska” przeszła na własność Katolickiego Towarzystwa Prasowego i stała się organem narodowego duchowieństwa katolickiego. Przemiana ta była związane z metamorfozą duchową Pawła Stalmacha, który na łożu śmierci zmienił wyznanie i przeszedł na katolicyzm. W tych okolicznościach „Gwiazdka” została organem prasowym Związku Śląskich Katolików, który w lutym 1923 r. połączył się z Polskim Stronnictwem Chrześcijańskiej Demokracji.

W XX w. „Gwiazdka” wystąpiła przeciwko wpływom socjalizmu i jego pokrewnym ruchom³ . Na łamach „Gwiazdki Cieszyńskiej” pisywali polscy działacze narodowi, m.in.: żołnierz Armii Błękitnej gen. Józefa Hallera, organizator polskiej oświaty na Górnym Śląsku, Władysław Górnikiewicz, a także debiutowało wielu nie tylko śląskich literatów. Byli to m.in.: Karol Miarka, Andrzej Cinciała, Jan Kubisz, Ernest Farnik, Józef Lompa, Jakub Bojko, ks. Jan Perges, Robert Zanibal i Juliusz Ligoń.

1 „Gwiazdka Cieszyńska”, nr 206 z 2 XI 1920, s. 2.

2 J. Drabina, Górny Śląsk, Wrocław 2002, s. 115-116; J. OLEKsIŃsKI, I nie ustali w walce, Warszawa 1980, s. 138.

3 „Gwiazdka Cieszyńska”, nr 206 z 2 XI 1920, s. 1. Zmierzch socjalizmu. 
Redaktorem „Gwiazdki Cieszyńskiej” w okresie wojny polsko-bolszewickiej był ksiądz katolicki Józef Londzin (1862-1929), zasłużony działacz społeczny i polityczny, historyk, burmistrz Cieszyna. Jako sekretarz Związku Śląskich Katolików, którym kierował od 1903 r., w 1907 r. i 1911 r. został wybrany do Rady Państwa w Wiedniu. W czasie I wojny światowej był członkiem Naczelnego Komitetu Narodowego. W październiku 1918 r. razem z Janem Michejdą, reprezentującym polskich ewangelików, oraz socjalistą Tadeuszem Regerem stanął na czele Rady Narodowej Księstwa Cieszyńskiego. Wiosną 1919 r. brał udział w konferencji pokojowej w Paryżu, gdzie bronił interesów ludności polskiej i walczył o przyłączenie większości Śląska Cieszyńskiego do Polski. Pragnienie to wyrażał wiersz Ślązaka zatytułowany Do pamiętnika :

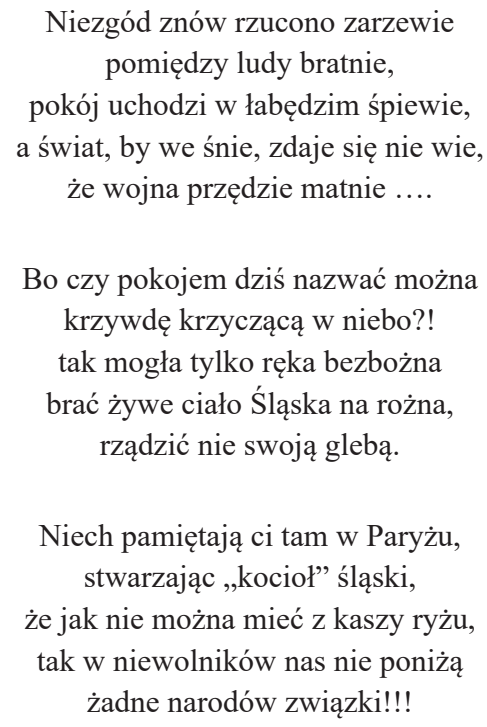

Tematyka i ton pisma dostosowywały się do wymagań chwili. Na początku obserwowało ono załamanie się wspólnoty interesów trzech potęg zaborczych, widziało uwikłanie się Austro-Węgier w sojusz z Niemcami, a następnie początki konfliktu tych państw z Rosją. Wreszcie śmiertelne zmagania tych mocarzy dotąd panujących nad tą częścią Europy. Uwagę dziennikarską przykuły zabiegi Wiednia i Berlina o przymierze z Polakami i zawiła gra dyplomatyczna Józefa Piłsudskiego. Podjął on wyzwanie zawarte w słowach Hugona Kołłątaja, jakie przekazał potomnym podkanclerzy w $L i$ stach Anonima: „Jeżeli się dziś nie dźwigniemy, będzie to znakiem, że nie chcemy,

4 „Gwiazdka Cieszyńska”, nr 172 z 3 VIII 1920, s. 1. 
że Ojczyzna i wolność są u nas rzeczą obojętną, że zepsucie narodu do tego przyszło stopnia, iż nie wart jest dłuższej na ziemi egzystencji”s. Przestroga ta wypowiedziana w epoce Sejmu Wielkiego nabrała aktualnego znaczenia w latach wielkiej wojny i walk o utrwalenie granic odradzającego się państwa. Zapadła też w pamięci i sercu redaktorów „Gwiazdki Cieszyńskiej”, którzy w 1920 r. skrupulatnie odnotowywali hojne ofiary krwi i mienia, jakich nie szczędzili Polacy dla urzeczywistnienia snu o niepodległej. Odrodzona Polska posiadała suwerenne władze, ale brakowało jej granic, o które od 1918 r. toczyła się walka dyplomatyczna i militarna.

W czasie niebezpiecznych zmagań z Rosją Sowiecką wiele stronnictw i ich organy prasowe atakowały Naczelnika Państwa. Wysuwały wobec J. Piłsudskiego oszczercze zarzuty, m.in. o brak udzielenia skutecznej pomocy Lwowowi walczącemu z Ukraińcami oraz opóźnianie powrotu do kraju wojsk gen. J. Hallera, Redakcja „Gwiazdki Cieszyńskiej” pod kierunkiem księdza J. Londzina przyjęła inną taktykę. W komunikatach z frontu wschodniego konsekwentnie pomijano osobę Wodza Naczelnego ${ }^{6}$, za to częściej pojawiało się nazwisko Wojciecha Korfante$\mathrm{go}^{7}$, Wincentego Witosa czy Ignacego Paderewskiego. Urodzony w patriotycznej rodzinie szlachty podlaskiej, wnuk powstańca 1863 r., bohaterski ksiądz Ignacy Skorupka (1893-1920), kapelan Wojska Polskiego, jawił się „Joanną d`Arc ossowskich pól"'. Z entuzjazmem pisano o zwycięstwach i przewagach oręża polskiego. $\mathrm{Z}$ troską wyrażano się o zagrożeniu niemieckim i czeskim ${ }^{9}$ oraz obojętności wobec sprawy polskiej mocarstw zachodnich ${ }^{10}$, w szczególności Angliii ${ }^{11}$, która w trudnych chwilach dla Polski, na galerii parlamentu gościła ludowego komisarza Leonida Krasina i członka Politbiura KC Lwa Kamieniewa ${ }^{12}$. Polityka czeskiego Edvarda Beneša, lidera Partii Narodowo-Socjalistycznej, bliskiego współpracownika Tomaša

\footnotetext{
${ }^{5}$ H. KolŁątaj, Do Stanisława Małachowskiego, referendarza koronnego. O przyszłym sejmie Anonima listów kilka, cz. 1. O podźwignięciu sił krajowych od 1 do 24 sierpnia 1788.

${ }^{6}$ Po bitwie warszawskiej nazwisko J. Piłsudskiego zaczęło się pojawiać częściej. Zob. „Gwiazdka Cieszyńska”, nr 197 z 1 X 1920, s. 6: Za obrazę Naczelnika.

7 „Gwiazdka Cieszyńska”, nr 193 z 17 IX 1920, s. 2; nr 215 z 3 XII 1920, s. 2; nr 37 z 10 V 1921, s. 1; nr 41 z 24 V 1921, s. 1; nr 45 z 7 VI 191, s 3.

8 „Gwiazdka Cieszyńska”, nr 187 z 27 VIII 1920, s. 2: Ku czci bohatera.

9 "Gwiazdka Cieszyńska”, nr 174 z 5 VIII 1920, s. 1: Rozbiór Ślaska; nr 177 z 8 VIII 1920, s. 2: Czesi żądaja całego Cieszyna, Nowy mord czeskich bojówek, Ślask Cieszyński frymarczony; nr 178 z 10 VIII 1920, s. 1: Ślask Cieszyński w czeskiej niewoli, s. 3: Tlumy domagają się opuszczenia Cieszyna przez wojsko czeskie; nr 179 z 11 VIII 1920, s. 4: Gwalty czeskie na Zaolziu; nr 185 z 20 VIII 1920, s. 4: Czesi rabuja Polaków i Rusinów; nr 195 z 24 IX 1920, s. 1: Zbrodnie czeskiej hakaty; nr 201 z 15 X 1920, s. 1: Cieszyn-Polska zrzekła się perty swej korony Czesi za bolszewikami.

10 „Gwiazdka Cieszyńska”, nr 176 z 7 VIII 1920, s. 2.

${ }^{11}$ Tamże. Zob. „Gwiazdka Cieszyńska”, nr 201 z 15 X 1920, s. 1.

12 „Gwiazdka Cieszyńska”, nr 181 z 13 VIII 1920, s. 1: Anglia w sprawie polskiej.
} 
Masaryka oraz uczestnika Konferencji Pokojowej w Paryżu - trafnie określiła jako „wyrafinowanego wroga Polski”'13.

Trzeba zauważyć, że chociaż jednym z zasadniczych celów pisma było szybkie i gruntowne informowanie o dziejach politycznych państw europejskich, zdarzały się jednak i lżejsze tematy. Dzięki temu „Gwiazdka Cieszyńska” cieszyła się dużym wzięciem. Zwłaszcza chętnie czytano żartobliwe dialogi Jury i Jonka spisane w pięknej śląskiej gwarze. Szły one w zawody z sensacjami politycznymi, opowieściami o fałszywych książętach i mesjaszach.Jednak w sierpniu 1920 r. nawet Jura i Jonek debatowali o Prusakach w Berlinie, ,co się radowali, że Polaków bolszewicy zmietą”14.

\section{ZA GÓRNY ŚLĄSK}

Drugie powstanie śląskie było odpowiedzią na tragiczne wydarzenia 16 i 17 sierpnia 1920 r., gdy Niemcy przekonani, iż Warszawę zdobyli bolszewicy, dokonali pogromu polskich działaczy, demolowali polskie lokale i demonstrowali pod hasłami: „Warschau gefallen” (Warszawa padła) i „Nieder mit Polen, nieder mit Frankreich!” (Precz z Polską, precz z Francją). Wśród ofiar znalazł się m.in. znany i szanowany katowicki lekarz Andrzej Mielęcki (1864-1920), którego skatowane ciało wrzucono do Rawy ${ }^{15}$.

Niemcy w swym zachowaniu nie byli odosobnieni. Również nad Wełtawą z euforią została przyjęta wieść o zdobyciu przez bolszewików Warszawy. W czeskiej prasie pojawiły się głosy, iż w tych sprzyjających okolicznościach należy pomyśleć o zagarnięciu reszty Śląska. Czesi zatrzymali setki wagonów z amunicją dla walczącej Polski, a ich polityk Edvard Beneš podjął przeciw Rzeczypospolitej szkodliwą ofensywę dyplomatyczną na europejskim forum ${ }^{16}$. Na linii Lundenburg ${ }^{17}-\mathrm{Bogu}-$ min zatrzymywali wszelkie transporty idące do Polski. Jak donosiła „Gwiazdka Cieszyńska”: „W ostatnich czasach zawrócili trzy pociągi «Wawelu» do Wiednia. Kolejarze czescy uchwalili [...] całkowity bojkot Polski i wezwali kolejarzy państw sąsiednich do przyłączenia się do tego bojkotu" ${ }^{18}$.

13 „Gwiazdka Cieszyńska”, nr 185 z 20 VIII 1920, s. 4.

${ }^{14}$ „Gwiazdka Cieszyńska”, nr 201 z 15 X 1920, s. 1.

15 Warschau gefallen. „Polska Zachodnia”, nr 187 z 18 VIII 1927; zob. „Górnoślązak”, nr 190 z 21 VIII 1920; J. PrZewlocki, W. ZielińsKi, Trzy sprawozdania Wojciecha Korfantego (lipiec - wrzesień 1920 r.), „Zaranie Śląskie”, 1971, z. 1, s. 163.

16 „Gwiazdka Cieszyńska”, nr 189 z 3 IX 1920, s. 1.

${ }^{17}$ Brzecław nad rzeką Dyją, 50 km na południowy wschód od Brna, nad granicą z Austrią.

18 „Gwiazdka Cieszyńska”, nr 193 z 17 IX 1920, s. 2: Nowe gwalty czeskie. 
Był to czas, gdy pruscy wojskowi rozważali zastosowanie w sprawie Górnego Śląska wariantu czeskiego na Zaolziu, tj. zająć zbrojnie i nie dopuścić do plebiscytu. Skłaniali się ku takiemu rozwiązaniu po tym, jak na Konferencji w Spa (5-16 lipca 1920) alianci sprawę Śląska Cieszyńskiego rozstrzygnęli na korzyść agresora. Mieli bardzo dobre rozeznanie jej przebiegu i gier zakulisowych, gdyż uczestniczyli w niej przedstawiciele Republiki Weimarskiej, minister finansów Joseph Wirth, minister Reichswehry Otto Gessler i jego zastępca Hans von Seeckt. Znali też zapatrywania premiera brytyjskiego Davida Lloyda George'a, który dał się poznać jako przeciwnik osłabiania Niemiec i kwestionował prawa Polski do obszarów należących wcześniej do Rzeszy. Według brytyjskiego historyka sir Michaela Eliota Howarda (1922-2019), najlepszego na Wyspach specjalisty od konfliktów zbrojnych, George podczas obrad paryskiej konferencji pokojowej „nietaktownie zażartował”, iż „oddać w ręce Polaków przemysł Śląska, to jak wkładać w łapy małpy zegarek" ${ }^{\prime \prime}$. Jako sygnatariusz traktatu wersalskiego realizował miłą Niemcom politykę negocjacji i porozumienia z Rosją bolszewicką, jako głównym partnerem nowego porządku geopolitycznego w Europie Wschodniej. W tym celu zapraszał do Londynu Lenina, by ustalić z nim kształt granic marionetkowej Rzeczypospolitej, bez dostępu do morza, bez Gdańska, Wilna, Grodna i Lwowa, bez Kresów Wschodnich, Górnego Śląska, a może i części Wielkopolski. David Lloyd George lansował politykę appeasementu, polegającą na zaspokajaniu żądań państw silniejszych i agresywniejszych. Nie było w jego koncepcjach miejsca na suwerenną Polskę. Usankcjonowany nowy rozbiór dopiero co odrodzonej Rzeczypospolitej miał zapewnić Zachodowi pokój. Jak zauważył prof. Andrzej Nowak, w opowieści „o pierwszej zdradzie Zachodu” dla brytyjskich elit Polska to było „nigdzie”, a Polaków postrzegano jak „egipskich niewolników”20. To Lloyd George doprowadził w ramach traktatu wersalskiego do obciążenia Polski częścią niemieckich długów i odszkodowań wojennych, co było ogromnym ciężarem dla zrujnowanej wojną gospodarki polskiej. I wreszcie 10 sierpnia $1920 \mathrm{r}$. na posiedzeniu parlamentu brytyjskiego, gdzie z wielkimi honorami był podejmowany Lew Kamieniew, oświadczył, iż warunki rozejmowe zaproponowane przez Lenina Polsce są dobre i nie wymagają udzielenia żadnej pomocy Polakom ze strony Wielkiej Brytanii ${ }^{21}$. W takich okolicznościach trudno dziwić się niemieckim rachubom.

\footnotetext{
${ }^{19}$ M. Howard, The Legacy of the First World War, w: Paths to War: New Essays on the Origins of the Second Word War, ed. by R. Boyce and E.M. Robertson, London 1989, s. 46.

${ }^{20}$ A. NowaK, Pierwsza zdrada Zachodu. 1920 - zapomniany appeasement, Kraków 2015, s. 13-14.

${ }^{21}$ A. NowaK, Niepodległa! 1864-1924. Jak Polacy odzyskali Ojczyznę, Kraków 2018, s. 308.
} 
$\mathrm{Na}$ ich charakter wpływ miała także sytuacja wewnętrzna. W opiniach postronnych obserwatorów w Republice Weimarskiej niewiele się zmieniło po klęsce poniesionej w pierwszej wojnie światowej. „Zdawałoby się, że tych ludzi, którzy stali na czele niemieckiego rządu, którzy byli powodem śmierci tylu set tysięcy obywateli i wprowadzili państwo do takiego upadku, będą tu nienawidzić" ${ }^{22}$. Tymczasem ,we wszystkich poważniejszych lokalach publicznych wisiały jeszcze wizerunki cesarza Wilhelma II, generalnego kwatermistrza armii niemieckiej Ericha Ludendorffa [założyciela masowej organizacji politycznej Tannenbergbund, który w swoich publikacjach dowodził, że wojna nie zakończyła się przegraną Niemiec Z.J.], admirała Alfreda von Tirpitza [twórcy Cesarskiej Marynarki Wojennej - Z.J.], nie mówiąc już o feldmarszałku Paulu von Hindenburgu [wybranym prezydentem Republiki Weimarskiej - Z.J.] i inne. Niemcy są tylko na zewnątrz republiką, wewnątrz monarchią. Przyznają oni to otwarcie" ${ }^{23}$ i to pewne, że ,nie na głos prezydenta, ale na głos cesarza wszyscy Niemcy staną jak jeden mąż" ${ }^{24}$. Można było nie raz w publicznym miejscu usłyszeć: „Nie mamy obecnie króla, ale przyjdzie czas wkrótce, że go mieć będziemy, aby ojczyzna zajaśniała w chwale"25.

Na podstawie rozmów i lektury niemieckiej prasy rodziły się opinie redaktorów „Gwiazdki Cieszyńskiej” na temat specyfiki mentalności i natury niemieckiej. Zazwyczaj wniosek był jeden, ,że charakter narodowy przeciętnego Prusaka nie doznał przez wojnę zmiany. Tak samo zarozumiała buta, taka sama nienawiść do wszystkiego co nie niemieckie. W duszy każdego gnieździła się żądza odwetu, zemsty"26.

Odbudowujące się, na przekór bismarckowskim i kaiserowskim ideom, państwo polskie było elementem rzeczywistości oddziaływającym jednocząco na całą scenę polityczną od komunistów po partię tzw. ,pastorów niemiecko-narodowych”. Zwołanie Polskiego Sejmu Dzielnicowego w Poznaniu obradującego w dniach 3-5 grudnia 1918 r. w kinie „Apollo” i Sali Lamberta uznano za wyraz „szaleństwa o wielkiej Polsce” oraz przejaw szowinizmu. W prasie nagłaśniano oskarżenia o niewdzięczność (za dobrodziejstwo, jakim był Akt 5 listopada), imperializm i katolicką nietolerancję wymierzoną przeciw Żydom, Litwinom i Białorusinom. Powszechnie negowano polskie aspiracje niepodległościowe, które znalazły wyraz w klauzuli traktatu wersalskiego, uznającej na mocy prawa międzynarodowego, po 123 latach niewoli, przy huku armatnich salw, niepodległą II Rzeczpospolitą.

\footnotetext{
22 „Gwiazdka Cieszyńska”, nr 189 z 3 IX 1920, s. 3.

${ }^{23}$ Tamże.

${ }^{24}$ Tamże.

${ }^{25}$ Tamże.

${ }^{26}$ Tamże.
} 
Pruskie narzekania na polską niewdzięczność miały długą tradycję. Po trzecim rozbiorze królewskie miasto Poznań zostało zaszczycone nowym tytułem prasowym. Było nim „Pismo Miesięczne Prus Południowych” gloryfikujące rządy zaborcze Berlina - prezentujące je Polakom jako „dar nieba”"27, chociażby w postaci niemieckich szkół. Niewdzięcznicy Wielkopolanie wkrótce jednak urządzili w $1806 \mathrm{r}$. powstanie i korzystając z pobytu w Berlinie Napoleona I wysłali do niego delegację, w której imieniu do cesarza przemawiał m.in. Ksawery Działyński, były poseł na Sejm Wielki, uczestnik powstania kościuszkowskiego i więzień pruskiego Spandau.

K. Działyński i jego towarzysze na tejże audiencji usłyszeli od imperatora: „Gdy ujrzę 30 do 40 tys. ludzi pod broń zebranych, ogłoszę w Warszawie niepodległość waszą"28. Niestety, po kongresie wiedeńskim i demontażu Księstwa Warszawskiego Poznaniacy ponownie trafili pod pruskie rządy, a Berlin uznał to za rozwiązanie ostateczne. „Breslauer Zeitung” w numerze 23 z 1861 r. pisała: „Nie przychodzi nam naturalnie na myśl, aby na rzecz zasady narodowościowej oddawać jaką́s cząstkę Wielkiego Księstwa Poznańskiego albo Prus Zachodnich czy nawet Górnego Śląska. Kraje te bowiem bardziej niż mieczem i traktatami zostały zdobyte faktycznie pługiem niemieckim. [...] Chcemy te kraje zatrzymać wbrew wszelkim pretensjom narodowego sentymentalizmu".

Powyższy problem trafnie ujęła „Gwiazdka Cieszyńska”, pisząc:

\begin{abstract}
Najbardziej spośród państw ententy nienawidzą Niemcy, co jest zresztą zrozumiale Francuzów, ale większą nienawiścią i wściekłą złością pałają przeciw Polsce. Polska uwalnia Polaków z niewoli pruskiej, Polska zabiera kraj, który był śpichlerzem i żywicielem całych Niemiec, najdroższą ich partę; tyle trudów włożyli w Poznańskie i Śląsk Niemcy, a teraz owoce wydziera im Polska. Czyż nie powód do strasznej złości, a to tym więcej, że robi to Polska, która była dotychczas pruską niewolnicą, a obecnie staje jako równe państwo! Toteż ta nienawiść jest bezgraniczna, przebija się w prasie pruskiej, w dyplomacji, w słowach i czynach hardego Prusaka ${ }^{29}$.
\end{abstract}

Zjawisko to dostrzegł także, nazwany w 2013 r. przez „Financial Times” - „największym żyjącym historykiem w Wielkiej Brytanii”, sir Michael Eliot Howard, którego książki są lekturą obowiązkową na wydziałach historii wielu uczelni na świecie. Pisał on:

\footnotetext{
${ }^{27}$ O polorze Prus Poludniowych pod panowaniem pruskim, „Pismo Miesięczne Prus Południowych”, styczeń 1803.

${ }^{28}$ Relacja o postuchaniu Ksawerego Działyńskiego, „Gazeta Warszawska”, nr 96 z 2 XII 1806.

${ }^{29}$ „Gwiazdka Cieszyńska”, nr 189 z 3 IX 1920, s. 3.
} 
Prusy posiadały te terytoria od XVIII wieku, inwestując intensywnie zarówno w przemysł Górnego Śląska, jak i rolnicze obszary Poznańskiego i Prus Zachodnich. [...] Polaków postrzegali oni tam jako rasę niewolniczą, Untermensch, którą należy traktować stanowczo, choć życzliwie. Gdy pod wpływem industrializacji polscy chłopi zasilili populację niemieckich miast, stając się lumpenproletariatem, ten stosunek do nich upowszechnił się w całej Rzeszy. Niemiecka postawa wobec Polaków mieściła się gdzieś pomiędzy stosunkiem Anglików do Irlandczyków w XIX w. a nastawieniem białych Południowoafrykańczyków do czarnych w XX w. [...] Ich [Brytyjczyków Z.J] doświadczenie kolonialne i irlandzkie sprawiało, że brytyjska klasa rządząca sympatyzowała w pewnym stopniu z niemieckim widzeniem Polaków jako podludzi ${ }^{30}$.

Dotyczyło to zarówno Górnoślązaków, jak i Wielkopolan.

Od 1919 r. prowadzono w całej Rzeszy kampanię przeciw ,zamykaniu narodu w żelaznej klatce” pod hasłami: „lepsza śmierć niż hańba”, „lepiej być martwym niż niewolnikiem". Nie godzono się z utratą Wielkopolski i Pomorza, nie zamierzano oddawać Polakom nawet najmniejszego skrawka Górnego Śląska. W kampanii tej uczestniczyli przywódcy niemieckich ruchów pacyfistycznych, m.in. Alfred Hermann Fried (1864-1921), założyciel Niemieckiego Towarzystwa Pokojowego (Deutsche Friedensgeselschaft). Krytykowano traktat wersalski ufundowany na gruzach porządku wiedeńskiego (1815 r.), zakładający m.in. słabość Niemiec i Rosji oraz uznanie nowych państw narodowych. Równocześnie, od czasów pertraktacji brzeskich 1918 r., utrzymywano w różnej formie i na różnych szczeblach kontakty z Rosją sowiecką.

Podobnie jak podczas wojny rosyjsko-polskiej $1831 \mathrm{r}$. i powstania $1863 \mathrm{r}$., wzorem pruskim wydano zarządzenia zabraniające przewozu towarów o charakterze militarnym do Rzeczypospolitej. Blokowano wszelką pomoc dla Polski walczącej z Armią Czerwoną. Niemieccy komuniści organizowali strajki przeciw wykorzystywaniu Górnego Śląska jako zaplecza materiałowego dla polskiej armii. Żądali zaniechania francuskich transportów wojskowych w imię neutralności. Na Śląsku propagowano hasło: Krieg dieses Krieges (wojna przeciw tej wojnie).

Berlin korzystał z doświadczeń, jakie nabyli Prusacy w okresie powstania listopadowego, gdy wspierali armię (urodzonego nieopodal Obornik na Śląsku, syna adiutanta Fryderyka Wielkiego) feldmarszałka Iwana Dybicza Zabałkańskiego (1785-1831), a później feldmarszałka Iwana Paskiewicza (1782-1856) w marszu na Warszawę. Wydarzenia polskie 1830 i 1863 r., podobnie jak wypadki 1794 r., wywarły duży wpływ na handel i życie gospodarcze Śląska. Wraz z rozpoczęciem powstania listopadowego pruski minister finansów Karl Georg Maasen i minister

${ }^{30}$ M. Howard, The Legacy of the First World War, s. 46. 
spraw wewnętrznych Gustaw Brenn wydali zarządzenie zabraniające wywozu do Polski pieniędzy, prochu, broni, zboża i koni. Zakaz wywozu broni do Królestwa (z 23 grudnia 1830 r.) głosił:

Powołując się na rozporządzenie paragraf 3 ustawy celnej z dnia 26 maja $1818 \mathrm{r}$. podajemy niniejszym do publicznej wiadomości, że najwyższym rozkazem królewskim z dnia $10 \mathrm{bm}$. zakazany został wywóz broni, koni, prochu, ołowiu oraz wszelkiego rodzaju innych artykułów wojennych przez granicę do Królestwa Polskiego. Kto, aż do zniesienia niniejszego zakazu, próbowałby wywozić wymienione przedmioty do Królestwa Polskiego, szczególnie przez pruską granicę od Schmalleninken nad Niemnem aż do głównej drogi celnej i do głównego urzędu celnego Zabrzeg na Górnym Śląsku, ten podlega karom przewidzianym w ustawie celnej z 26 maja 1818 r. paragraf 111 i następne, przeciwko wywozowi rzeczy, które państwo wywozić zakazało ${ }^{31}$.

\section{Władze lokalne uzupełniły powyższy dekret komentarzem:}

Zarządzenie ministerialne podaje się niniejszym do publicznej wiadomości w tym celu, by wszyscy do niego stosowali się. Równocześnie nakazuje się wyraźnie odnośnym władzom policyjnym, aby one współdziałały w czuwaniu nad zakazanym wywozem i w razie potrzeby przy tym pomagały granicznym urzędnikom celnym ${ }^{32}$.

W 1920 r. rząd Republiki Weimarskiej umiejętnie udzielał wsparcia marszałkowi Michaiłowi Nikołajewiczowi Tuchaczewskiemu. Fakty na temat współpracy niemiecko-bolszewickiej ujawnił 19 lipca 1920 r. wysokonakładowy brytyjski dziennik społeczno-polityczny „The Times” wydawany w Londynie. „Gwiazdka Cieszyńska” wykorzystała opublikowany materiał, przekazując polskiemu czytelnikowi relacje za korespondentem znad Tamizy. Według gazety 18 lipca 1920 r. czterdziestu oficerów niemieckich, w ubraniach cywilnych, wyjechało ze Szczecina do Helsingforsu (Helsinek). Jechali przez Finlandię do Rosji, aby szkolić oddziały Armii Czerwonej. W tym czasie setki innych niemieckich oficerów były już na miejscu. Liczyli oni, że gdy armia sowiecka wkroczy w głąb Polski, Niemcy ofiarują wówczas swoje usługi. Pójdą niby na pomoc Polsce, lecz w decydującym momencie połączą się z Rosjanami. „Fakty te są z pewnością znane rządom sprzymierzonym, jak również to że Niemcy mają istotnie pod bronią milion ludzi i olbrzymie zapasy materiału

31 „Amts-Blatt der Koeniglich-Preussischen Regierung zu Marienwerder”, 1831, nr 2, s.15-16. Decyzje dotyczące wywozu materiałów wojennych ze Śląska, jakie podjęły władze pruskie w okresie powstania listopadowego, były wzorowane na edyktach królewskich, m.in. z 16 maja i 6 czerwca 1794 r. publikowanych na łamach miesięcznika „Schlesische Provinzialblatter”, które zabraniały eksportu do Rzeczypospolitej żelaza, narzędzi i surowców do produkcji kos.

32 „Amts-Blatt der Koeniglich-Preussischen Regierung zu Marienwerder”, 1831, nr 2, s.15-16. 
wojennego. Niebezpieczeństwo jest groźne!”33 - konkludowała „Gwiazdka Cieszyńska”. W innym numerze konstatowała, iż Niemcy zdradziły cywilizację popierając najazd barbarzyńców ${ }^{34}$.

Tymczasem Niemcy łudzili się nadzieją, iż powtórzy się sytuacja z września 1831 r., która doprowadziła do kapitulacji stolicy Królestwa Polskiego i upadku sprawy polskiej. Na taką okoliczność przygotowali scenariusz działań, który przedstawili Międzysojuszniczej Komisji Plebiscytowej w nocie z 17 sierpnia 1920 r. Powołując się na naciski bolszewików domagających się internowania wycofujących się wojsk polskich na Pomorzu, w Prusach Wschodnich i na Górnym Śląsku, rząd niemiecki uprzedzał aliantów, iż nie może dopuścić do przekształcenia Górnego Śląska w bazę operacyjną w czasie wojny między Polską i Rosją, nie narażając się na zbrojną reakcję Moskwy. Notę z 17 sierpnia 1920 r. ożywił duch konwencji Alvenslebena zawartej z inwencji Otto von Bismarcka 8 lutego 1863 r. w Petersburgu z Imperium Rosyjskim. Układ dotyczył wzajemnej współpracy w tłumieniu polskiego powstania.

Poczynania polityków Republiki Weimarskiej wspierała prasa. Ona również miała bogate tradycje w działaniach popierających współpracę Rosji i Prus. Na przykład „Breslauer Zeitung” w 1831 r. nie ukrywała oburzenia, że Polacy występowali przeciwko władzy prawowitego monarchy. Polemizowała także w sposób tendencyjny z polskimi roszczeniami terytorialnymi wobec Rosji o przynależność tzw. Ziem Zabranych (litewsko-ruskich). Gazeta ta często wyrażała dezaprobatę wobec wiadomości np. „Gazety Warszawskiej”. W 1831 r., nie bez satysfakcji, „Breslauer Zeitung” informowała o sukcesach wojsk rosyjskich, zamieszczając m.in. bardzo obszerny biogram Iwana Dybicza ${ }^{35}$. Sytuacja w 1920 r. w pewnym sensie powtarzała się kolejny raz w dziejach. W Berlinie ogarniętym rewolucją i zdominowanym niechęcią do zmartwychwstającej Polski rosły sympatie do Armii Czerwonej i Kraju Rad.

Mimo głębokich wewnętrznych podziałów politycznych i rewolucyjnych rozterek, oprócz działań propagandowych, Niemcy podjęli duży wysiłek organizacyjny. Według ocen strony polskiej

siłę organizacji niemieckich zakonspirowanych na terenie plebiscytowym, można było obliczyć na czterdzieści tysięcy ludzi, dla których potrzebna broń i amunicja nagromadzona była w rozmaitych ekspozyturach tajnych, kopalniach itp. W większej części była to broń przygotowana w rozmaitych składnicach na terenie graniczącym ze Śląskiem. Dowódcami wszelkich organizacji bojowych niemieckich byli oficerowie armii czynnej, albo oficerowie rezerwy bojowo wyszkoleni. Rozkazy odbierali wprost

\footnotetext{
33 „Gwiazdka Cieszyńska”, nr 162 z 22 VII 1920, s. 3. Niemcy sojusznikami bolszewików.

34 „Gwiazdka Cieszyńska”, nr 180 z 12 VIII 1920, s. 3.

35 „Breslaer Zeitung”, z 3 II 1831.
} 
z Berlina i byli w ścisłej łączności ze sztabem generalnym niemieckim. [Ponadto uwagę zwracał fakt], że wszystkie organizacje niemieckie - zazwyczaj bardzo rozbieżne pod względem politycznym - częściowo nawet będące organem rozmaitych partii politycznych zwalczających się nawzajem zaciekle, tworzyły jeden karny zespół gdy chodziło o sprawę Górnego Śląska ${ }^{36}$.

Odzwierciedleniem niemieckiego solidaryzmu była pruska prasa, która bez względu na opcję polityczną pisała $\mathrm{w}$ tym samym antypolskim tonie. Z żądzy odwetu rozpowszechniała najstraszniejsze potwarze przeciw i o Polsce. „Gwiazdka Cieszyńska” pisała, iż niemiecka prasa wobec wojny zajęła „stanowisko bolszewickie" rozpisując się głównie na temat polskich porażek militarnych. Według niej Rzeczpospolita pod naporem bolszewików przestała już istnieć. W Polsce panował „bezład i nieporządek”. „Gdzie wstąpią Polacy, tam według tej prasy mordują i rabują, bolszewicy zaś zaprowadzają wszędzie porządek". Jakby tego było mało, aby podtrzymać nienawiść u obywateli niemieckich, prasa podawała fałszywe wieści o okrucieństwach Polaków, popełnianych m.in. na „poznańskich Niemcach”. Za przykład służyła sfabrykowana wiadomość z Grudziądza, gdzie według „całej prasy niemieckiej" wojsko polskie zamordowało 16 robotników, ponieważ byli Niemcami. Tylko „Gwiazdka Cieszyńska” podała, iż niemieckie ministerstwo zbadało tę sprawę i okazało się, że to zupełny fałsz. I mimo udostępnienia wyniku dochodzenia ministerialnego agencjom prasowym, żadna z gazet, z wyjątkiem „Die Welt”, nie odwołała pomówienia Polaków o zbrodnię. Ta ostatnia jednak nie kierowała się „naruszonym honorem Polski”, lecz niepotrzebnym niepokojeniem obywateli ${ }^{37}$.

\begin{abstract}
Z wściekłości tej - pisała „Gwiazdka Cieszyńska” - rzuca prasa niemiecka na Polskę coraz szkaradniejsze potwarze, wymyśla kłamstwa, przeklina Ją, ogłaszając, że z Jej winy pochodzi wszystko zło w Niemczech i na świecie. Według tej prasy bolszewizm w Rosji powstał z odwiecznej nienawiści mas rosyjskich do Polski i te masy teraz nie chcą pokoju, byle tylko nienawistną Polskę zgnieśćc ${ }^{38}$.
\end{abstract}

Zarówno wydawany w nakładzie 300000 egzemplarzy przez Hansa LachmannaMosego „Berliner Tageblatt” ${ }^{9}$, na którego łamach publikowali felietony Alfred Polgar, Kurt Tucholsky, Otto Flake, Frank Thies i Erich Kastner, jak i „Berliner Lokal-Anzeiger" ${ }^{40}$, powielały wszystkie kłamstwa i wyrażały gwałtowną reakcję

\footnotetext{
${ }^{36}$ M. MIELŻYŃSKI, Wspomnienia i przyczynki do historii III-go Powstania Górnośląskiego, Mikołów 1931, s. 50.

37 „Gwiazdka Cieszyńska”, nr 189 z 3 IX 1920, s. 3. Wyspa Rugia-Niemcy wobec Polski.

38 Tamże.

39 „Berliner Tageblatt”, nr 359 z 2 VIII 1920.

40 „Berliner Lokal-Anzeiger”, nr 367 z 6 VIII 1920.
} 
uczuciową. Najpopularniejszy dziennik „Berliner Lokal-Anzeiger”, nazywany w podtytule „Centralnym Organem Stolicy Rzeszy”, kolportowany w nakładzie 200 000, omawiając odezwę bolszewicką do niemieckich robotników, wzywającą do odmowy jakiejkolwiek pomocy Polsce, kończył drwiąco i z przekąsem: „Kein Mensch denkt daran und kann daran denken für dieses elende Polenreich auch nur mit einem kleinen Finger zu rücken" (Nikt nie myśli o tym, i nie marzy nawet o poruszeniu małym palcem dla tego nędznego polskiego imperium ${ }^{41}$.

Prawie każdy numer gazet niemieckich jakiegokolwiek kierunku politycznego naszpikowany był „kolcami” przeciw Polsce. Według „Gwiazdki Cieszyńskiej” opinia publiczna niczym nie różniła się od prasy. „Nikt tu o Polsce dobrze nie mówi pisała śląska gazeta - ani też cierpią Polaków. To, że w Raciborzu o mało nas nie poturbowano za to, żeśmy po polsku między sobą rozmawiali, nic dziwnego, bo tu teren plebiscytowy, ale także [...] daleko od granic, nie jest lepiej. Prawie ciągle słyszy się ujadanie na wszystko co polskie, widzi się radość, jaką sprawia każda wiadomość o niepowodzeniu Polski” ${ }^{2}$. Na wiadomość, iż bolszewicy przerwali front, reagowano okrzykiem: Jetzt gene die Polenschon zu Grunde, die verfluchten Halunken! (Teraz Polacy są zrujnowani, przeklęci łajdacy!) ${ }^{43}$. Wiele mówiono o Polsce, ,ale każde słowo było kamieniem obrazy dla uczuć polskich" ${ }^{44}$. Przy okazji zaczęto drukować rysunki satyryczne drwiące z Francuzów, przedstawiające przybyszów znad Sekwany jako tchórzy i chciwców.

Niemcy, skoro pojawiły się sprzyjające im okoliczności, podjęli przygotowania do „oswobodzenia Śląska spod władzy aliantów i ostatecznego zgniecenia polskości”. Działali pod wpływem niekorzystnych dla Polaków wypadków na przedpolu Warszawy. Bliskość Rosjan „dodała otuchy kierującym sferom niemieckich bojówek w mundurach zielonej policji i w ubraniach cywilnych (82 000). Ruchem kierował rząd niemiecki. Bojówki miały przygotowane składy broni, materiałów wybuchowych, armaty, stacje radiotelegraficzne itp. Urządzenia [te zgromadzono Z.J.] w celu skuteczniejszego prowadzenia ruchu zbrojnego"45. Dnia 28 maja 1920 r. rozpoczęły się niemieckie napady na Polski Komitet Plebiscytowy zlokalizowany w bytomskim hotelu „Lomnitz”, siedzibę Wojciecha Korfantego.

Rozwój wydarzeń na Górnym Śląsku bacznie śledziła i komentowała redakcja „Gwiazdki Cieszyńskiej”. Nie tylko zauważyła nagonkę na przyjaznego Polakom wizytatora apostolskiego na Polskę i Litwę papieża Benedykta XVI - nuncjusza

\footnotetext{
${ }^{41}$ „Gwiazdka Cieszyńska”, nr 189 z 3 IX 1920, s. 3.

42 Tamże.

${ }^{43}$ Tamże.

${ }^{44}$ Tamże.

45 „Gwiazdka Cieszyńska”, nr 190 z 7 IX 1920, s. 3. Co się dzieje na Górnym Śląsku.
} 
Achille Rattiego ${ }^{46}$. W artykule pt. Rozbrojenie francuskich oddziałów na Górnym Śląsku czytamy, iż 14 sierpnia 1920 r. ,Raciborski Związek Pracowników Zawodowych zatrzymał transport francuskich oddziałów. Pociąg został przesunięty na martwy tor, którego strzegli robotnicy Związku. Miano także zatrzymać pociągi transportowe w Tworkowie i Anabergu [Góra św. Anny - Z.J.]. Pracownicy żądali, żeby w czasie wojny rosyjsko-polskiej nie odbywało się żadne przesuwanie wojsk koalicyjnych, pozostających na Górnym Śląsku" ${ }^{47}$. Zdaniem redakcji powodem niemieckiej akcji był francuski kontyngent stacjonujący na Zaolziu, który po rozgraniczeniu Śląska między Polskę i Czechy wyjechał dla wzmocnienia wojsk koalicyjnych na Górny Śląsk. Stacjonujący tutaj Francuzi musieli coraz bardziej mieć się na baczności. 15 sierpnia 1920 r. potężna eksplozja na gliwickim dworcu spowodowała śmierć trzech żołnierzy i kolejarza. Odpowiedzialność za akt terroru ponosili członkowie niemieckiej bojówki, którzy uprowadzili parowóz i skierowali go w pełnym pędzie na stojący na bocznicy francuski pociąg z amunicją.

W kolejnym numerze „Gwiazdki” tytuł doniesienia Niemcy na Górnym Ślasku podnosza głowę budził niepokój polskiego czytelnika. Wytłuszczonym drukiem w telegraficznym skrócie charakteryzowała ona stan rzeczy po 17 sierpnia. „Demonstracje niemieckie. Wojsko francuskie strzela. 10 zabitych, 30 ciężko rannych. Wzburzenie ludu. Francuzi zgadzają się na rozbrojenie wojsk francuskich"48. Komentarz redakcji zwracał uwagę, iż wojska francuskie od początku swej bytności na Górnym Śląsku „nie były lubiane przez Niemców”. Ciągle nadchodziły wieści o burdach ulicznych między żołnierzami francuskimi a ludnością niemiecką. Wzmagały się one „równolegle do niepowodzeń Polski na froncie” wschodnim. Po rozbrojeniu francuskich żołnierzy, którzy z Cieszyna chcieli przejechać na Górny Śląsk, niemieccy robotnicy rozpoczęli strajk wymierzony w transporty wojsk francuskich zmierzające na Górny Śląsk.

Strajkujący unieruchomili m.in. centrale elektryczne w Chorzowie i Zabrzu. Na rozkaz organizacji niemieckich kupcy niemieccy zamknęli swoje sklepy, a po południu o godzinie $17.00 \mathrm{w}$ kilku miastach okręgu przemysłowego odbyły się niemieckie wiece. Jak pisała „Gwiazdka Cieszyńska”, najkrwawszy przebieg miały demonstracje w Katowicach, gdzie zaatakowano kamieniami francuskich żołnierzy. „Jednego żołnierza tłum ściągnął z konia i zabił na miejscu”49. Wojsko odpowiedziało ogniem karabinowym. „Tłum rozproszył się. Na polu zajścia zostało 10 za-

\footnotetext{
46 „Gwiazdka Cieszyńska”, nr 177 z 8 VIII 1920, s. 3. Nagonka Niemców na nuncjusza Rattiego.

47 „Gwiazdka Cieszyńska”, nr 184 z 17 VIII 1920, s. 3.

48 „Gwiazdka Cieszyńska”, nr 185 z 20 VIII 1920, s. 2.

${ }^{49}$ Tamże.
} 
bitych (wśród nich dwóch członków Sicherheitswehry) i 30 rannych"50. Nie oznaczało to jednak końca niepokojów. Rozwścieczony tłum zebrał się przed siedzibą Międzysojuszniczej Komisji Rządzącej i Plebiscytowej, zdobył francuski automobil wojskowy i rozpoczęło się polowanie na polskich działaczy narodowych. Jedną z ofiar był lekarz Andrzej Mielęcki, pod którego adresem wznoszono nienawistne okrzyki, m.in. Das war der Polenkönig Dr Mielęcki, raus mit ihm, lynchen muss man den Hund! (dr Mielęcki to polski król, wynocha z nim, zlinczować psa!) ${ }^{51}$.

Jednak na tym nie poprzestano.

Z podwórza wywleczono nieszczęśliwego na ulicę dla zabawki wściekłego motłochu. Podniosły się kije, laski, żelazne druty, siekąc niemiłosiernie ciało lekarza. Zajechał wóz sanitarny. Mordercy, myśląc, że dr Mielecki nie żyje, porwali leżące ciało i rzucili je do wozu. Nieszczęśliwa ofiara bestialskich instynktów motłochu dawała jeszcze znaki życia. Ten resztek życia na nowo podburzył tłum, który znów z dzikim rykiem rzucił się na wóz i popędził z nim w stronę rzeczki - Rawy. Nad brzegiem wyrzucono konającego z wozu, ażeby dokonać zemsty na „,polskim królu”. A jest to rzeczywiście król polskich męczenników górnośląskich. Oprawcy zdarli z niego resztki odzieży i zaczęli tak długo bić i kopać, aż nie pozostało na nim ani jedno zdrowe miejsce. Kilku zwyrodniałych opryszków wytłoczyło deski z wozu ratunkowego, dobijając nimi dr. Mielęckiego. I gdy przed nimi leżał tylko nieruchomy, poszarpany, sino-krwawy trup bez kształtu, masa z błota i krwi, rzuciło go do brudnej, mętnej rzeki ${ }^{52}$.

Także w innych miejscowościach miały miejsce podobne incydenty. W Rybniku doszło do krwawych starć z Polakami. Podczas strzelaniny zostało kilka osób zabitych i kilkanaście rannych. Wśród ciężko pobitych przez Sicherheitswehrpolitzei Polaków znalazł się m.in. członek Rady Miejskiej, adwokat dr Marian Różański, o którym „Gwiazdka Cieszyńska” mylnie doniosła, iż został zabity ${ }^{53}$.

Mimo tego drobnego potknięcia redakcja „Gwiazdki Cieszyńskiej” dokonała trafnej oceny przebiegu wydarzeń w artykule Niemcy zamierzali opanować Górny Ślask.

Niemcy górnośląscy spodziewali się, że Warszawa zostanie zdobyta przez bolszewików i że wówczas Górny Śląsk dostanie się pod panowanie Niemiec. Przygotowywali oni przy pomocy Berlina zamach stanu, chcieli wyrzucić garnizony francuskie i włoskie

\footnotetext{
${ }^{50}$ Tamże.

${ }^{51}$ Der Aufstand im oberschlesischen Abstimmungsgebiet, August und September 1920, II Anlagen, Berlin 1920, s. 12.

52 J. PiernikarCZYK, Ilustrowana Księga Pamiątkowa Górnego Śląska, Katowice 1923, s. 41.

53 „Gwiazdka Cieszyńska”, nr 185 z 20 VIII 1920, s. 2. Zob. M. Różański (1864-1927), https://www. ipsb.nina.gov.pl/a/biografia/marian-rozanski-rozanski
} 
z obszaru plebiscytowego, objąć na powrót władzę i dokonać połączenia z republiką niemiecką. Udało im się to tylko po części, bo wyparli Francuzów na krótki czas z Bytomia, lecz zaraz nastąpił zwrot, bo Francuzi otrzymawszy nowego komendanta, wtargnęli na powrót do miasta i siłą zbrojną zmusili Niemców do spokojnego zachowania się. To samo stało się w Katowicach i Bogucicach ${ }^{54}$.

Z kolei na podstawie doniesień z Opola „Gwiazdka Cieszyńska” pisała:

W Katowicach Komisja koalicyjna ogłosiła 18 bm. obostrzony stan oblężenia. Od godziny 8.00 wieczorem ruch uliczny jest zakazany. Mimo to przyszło jednak w Katowicach do nowych rozruchów. Niemcy napadli na siedzibę powiatowego komitetu plebiscytowego w hotelu „Deutsches Haus”, który podpalili. Personel komitetu był zmuszony w obronie własnej użyć broni. W końcu jednak wobec przewagi musiał się poddać. Ponieważ wojska francuskie wyszły z miasta, Polacy byli zdani na łaskę i niełaskę Niemców. Sicherheitswehr aresztowała członków komitetu. Niektórych nawet zamordowano. Niemcy urządzili napad na redakcję „Gazety Ludowej” i zdemolowali urządzenie redakcji. Napadnięto również kilka polskich sklepów, a zwłaszcza jubilerów, które zrabowano ${ }^{55}$.

Niesprawdzona wiadomość o zajęciu przez Rosjan Warszawy wprawiła Niemców niemal w hipnotyczny trans. „Wszyscy gotowi byli poświęcić się bolszewizmowi tylko po to, aby bolszewizmu użyć do przeprowadzenia swego zamiaru zemsty, oswobodzenia ojczyzny i zapanowania nad światem"56.

Druga połowa sierpnia 1920 r. obfitowała na prasowych łamach nie tylko najciekawszymi wiadomościami pod względem politycznym, lecz także dziennikarskim. „Gwiazdka Cieszyńska” publikowała w tym okresie po reportersku ujęte opisy ofensywy armii sowieckiej i bohaterstwa polskiego żołnierza broniącego dostępu do Warszawy - serca Polski. Obfitość zebranych szczegółów i taktowny ton tych reportaży dobrze świadczyły o umiejętnościach warsztatowych autorów. Rozpisywano się na temat walk wokół Sokołowa i wzdłuż Bugu od Kodnia po Włodzimierz Wołyński, wyrażano podziw dla odwagi obrońców Ostrołęki i Łomży ${ }^{57}$, Ossowa i Radzymina ${ }^{58}$. Z trwogą obserwowano marsz 16. Armii Nikołaja Sołłohuba w kierunku warszawskiego przedmościa, któremu towarzyszył na północy wielki manewr oskrzydlający 4. Armii Aleksandra Szuwajewa wraz z III Korpusem Konnym GajChana. 14 sierpnia nad ranem forpoczty Gaj-Chana pojawiły się nad Wisłą między

\footnotetext{
${ }^{54}$ „Gwiazdka Cieszyńska”, nr 186 z 24 VIII 1920, s. 2.

55 Tamże. Zob. J. Mrowiec, Opis napadu na Polski Komisariat Plebiscytowy w Katowicach w sierpniu 1920 r., „Powstaniec Śląski”, nr 11 z XI 1935, s. 27-38.

56 „Gwiazdka Cieszyńska”, nr 189 z 3 IX 1920, s. 3.

57 „Gwiazdka Cieszyńska”, nr 178 z 10 VIII 1920, s. 1.

58 „Gwiazdka Cieszyńska”, nr 187 z 27 VIII 1920, s. 2.
} 
Nieszawą i Bobrownikami, a następnego dnia M. Tuchaczewski podpisał rozkaz o formowaniu Pierwszej Polskiej Armii Czerwonej. W tak dramatycznych okolicznościach opublikowano na łamach „Gwiazdki Cieszyńskiej” posłanie Do ludów świata $^{59}$, a 16 sierpnia rozpoczęło się decydujące przeciwuderzenie wojsk polskich z rejonu Wieprza w kierunku Mińska Mazowieckiego, Brześcia Litewskiego i Siedlec. Grupą uderzeniową osobiście dowodził J. Piłsudski.

\section{OD „CUDU NAD WISŁĄ” DO „CUDU NAD ODRĄ”}

Zaskoczeniem dla rozzuchwalonych Niemców było doniesienie o kontrofensywie Józefa Piłsudskiego i tzw. cudzie nad Wisłą, który diametralnie zmienił dotychczasowy stan spraw politycznych na Górnym Śląsku. Mimo to Francuzom udało się opanować sytuację w Katowicach dopiero 19 sierpnia, gdy delegowany z Opola, energiczny gen. Jules Victor Gratier (1863-1956), Naczelny Dowódca Wojsk Sprzymierzonych na Górnym Śląsku, wydał jak najostrzejsze rozkazy zakazujące zbiegowisk oraz sprowadził kilka samochodów pancernych i wysłał na ulice wzmocnione patrole. Kolejne szczegóły dotyczące niemieckiej aktywności zaczerpnęła „Gwiazdka Cieszyńska” z korespondencji berlińskiej. Na podstawie zawartych w niej opisów ustalono, iż miasto Katowice dzięki działaniom gen. J.V. Gratiera „przybrało odmienny obraz. O ile do wczoraj żaden francuski żołnierz nie ukazał się na ulicach [...] to obecnie po ściągnięciu silniejszych kontyngentów, oddziały francuskie opanowały w zupełności sytuację"60.

Surowo potraktowano delegację niemiecką, której oświadczono w sposób stanowczy, iż „nie może wtrącać się do wydanych zarządzeń” wojskowych, ani stawiać żadnych żądań ${ }^{61}$. W przypadku ponownego zjawienia się podobnej deputacji ostrzeżono, że zostanie aresztowana i przetrzymana w charakterze zakładników. Po godzinie 6.00, w czwartek, $19 \mathrm{bm}$. wkroczyły na plac Teatralny oddziały francuskie, tamże ustawił się samochód pancerny i oddział karabinów maszynowych. „W chwili gdy po godzinie 6.00 wieczorem poczęli napierać demonstranci, patrole francuskie dały ognia. Tłum rozbiegł się, atoli po jakimś czasie począł ponownie napierać, wówczas wprawiono w ruch karabin maszynowy i samochód pancerny. [...] Około godziny 7.00 nowe grupy demonstrantów zaczęły jednak ponownie napierać, a wówczas samochód pancerny wyjechał na ulice miasta w stosownej eskorcie,

\footnotetext{
59 „Gwiazdka Cieszyńska”, nr 179 z 11 VIII 1920, s. 1.

${ }^{60}$ „Gwiazdka Cieszyńska”, nr 186 z 24 VIII 1920, s. 2.

${ }^{61}$ Tamże.
} 
dając gęste salwy [...] O godzinie 8.00 wieczorem przywrócono spokój”. Artykuł kończyły słowa: „Liczba ofiar jest nieznana”62. Natomiast źródła niemieckie pisały, iż wskutek tak bezwzględnego postępowania „rozgrywały się niesłychane sceny"63. W obiegu były różne liczby poszkodowanych. Krzysztof Brożek odnotował w pierwszym dniu zamieszek katowickich 8 zabitych, 12 ciężko rannych i 6 lekko rannych ${ }^{64}$, a zagłębiowski „Głos Pracy” - 1 żołnierza francuskiego, z cywilów 9 zabitych, w tym 2 funkcjonariuszy Sicherheitswehry, oraz 27 rannych ${ }^{65}$. Dane te nieco różnią się od podanych przez „Gwiazdkę Cieszyńską”, która podsumowując „bitwę na ulicach Katowic” na podstawie źródeł berlińskich podała, iż „po stronie niemieckiej było 20 zabitych, między nimi major Sicherheitswehry z Katowic, von Kleist", a po francuskiej 9 ofiar $^{66}$.

Trwałym śladem krwawych utarczek z Niemcami jest pomnik w formie sarkofagu w gliwickim Parku Starokozielskim, będącym pozostałością po dawnym cmentarzu przy ulicy Kozielskiej. Upamiętnia on 71 żołnierzy i oficerów francuskich, którzy zginęli z rąk niemieckich podczas służby w latach 1920-1922 na terenie Górnego Śląska. Napis na jego frontonie głosi: „Żołnierzom francuskim, synom zaprzyjaźnionego narodu, poległym za Francję, Polskę i ludzką godność. Wdzięczni Polacy”.

Były to ciężkie chwile dla polskich mieszkańców nie tylko Górnego Śląska. Dopiero gdy „Gwiazdka Cieszyńska”, po komunikatach: „Linia Wisły musi być utrzymana, Stan oblężenia w Warszawie, Kapłani na stanowisku”, sformowana została „Zachodnia armia rezerwowa, Bolszewicy hulają" - doniosła na stronie tytułowej „Bolszewicy pobici”, a później pojawiły się wieści „Z pola walki: Zwycięski pochód naszej armii, Odcięcie lewego skrzydła bolszewików na północy, Linia Narwi przekroczona" ${ }^{67}$, wówczas nowy duch wstąpił w Górnoślązaków. Od dnia tego wymodlonego zwycięstwa również członkom POW G.Śl. Józef Piłsudski pokazał się jako ten, który „,podjął Ojców rdzewiejący miecz”, który zbudził Polskę „z hańbiącej niewoli”, a Stanisław Rostworowski, działacz plebiscytowy i organizator trzeciego powstania, w publikacji Wódz i naród napisał o marszałku: „Piłsudski odwrócił karty naszych dziejów i stając się własnością narodu wycisnął piętno na powszechnym biegu naszego życia”.

\footnotetext{
${ }^{62}$ Tamże.

${ }^{63}$ Tamże.

${ }^{64}$ K. BRożEK, Andrzej Mielęcki, lekarz specjalista chorób kobiecych w Katowicach, w: Dr Andrzej Mielęcki-lekarz, humanista, działacz społeczny, oprac. R. Brom, J. Malicki, J. Śliwiok, Katowice 2004, s. 15.

${ }^{65}$ „Głos Pracy”, nr 187 z 19 VIII 1920.

${ }^{66}$ „Gwiazdka Cieszyńska”, nr 186 z 24 VIII 1920, s. 2.

67 „Gwiazdka Cieszyńska”, nr 186 z 24 VIII 1920, s. 1.
} 
Najwłaściwiej znaczenie zwycięstwa ocenił francuski gen. Maxime Weygand we fragmencie pamiętnika La Bataille de Varsovie, ogłoszonym w „Revue des Deux Mondes" z 15 marca 1957 r. Trafna była także jego ocena roli Naczelnego Wodza, gdy pisał, że marszałek Piłsudski „w ciągu trzech dni spędzonych pośród swych wojsk zelektryzował je”; że „potrafił on przelać ze swej duszy w dusze kombatantów swoją ufną wiarę i swoją wolę tryumfalnego pokonania wszystkich trudności"; że „nikt inny poza nim nie mógł się o to pokusić”. Nic też nie można dodać do słów autora pamiętników, gdy nieco dalej mówił, że „wyzyskanie powodzenia było prowadzone mistrzowską ręką, diabelskim rozpędem i z namiętną energią przez marszałka Piłsudskiego, który nie dał zaskoczonemu nieprzyjacielowi ochłonąć i na miejscu go unicestwił" ${ }^{68}$.

Do tego czasu Polacy na Górnym Śląsku mogli tylko gorliwie modlić się w kościołach na intencję zwycięstwa, lub śpiewać pieśni patriotyczne, jak to było m.in. w domu dr. Andrzeja Mielęckiego. Poczuciu własnej bezsilności, poddaniu się losowi towarzyszyła głęboka wiara w łaskę Bożą wobec „Czerwonego Potopu”. W tej sytuacji „Gwiazdka Cieszyńska” jako wzór do naśladowania stawiała twórcę Błękitnej Armii. „I wówczas, dziesięć dni temu, gdy generał Józef Haller zarządził ośmiodniowe nabożeństwo [na intencję - Z.J.] oręża polskiego w obronie Warszawy - Polski i sam razem z tłumem nabożnych przystępował codziennie do Komunii Św., modlili się wszyscy o cud Wisły" "69. Przemianę nastrojów i postaw różnych grup narodowościowych na Śląsku dobrze oddawał dialog prostych śląskich chłopów - Jonka i Jury: „Isto jednak nas Pónbóczek mają radzi. Już, się zdało, że nas ci czerwoni zbóje mongolscy zaleją, a tu naroz kij się obrócił i młóci po zadkach bolszewickich. Dyć się bali w Cieszynie panikierzy, najbardży żydzio na bolszewików radowali - też im zgizło, chodzą jak psy bez chwosta" ${ }^{\text {" }}$. Na co Jura odpowiedział: „[...] myślę, to się będzie sumerya robić w Rosyji, jeny jeszcze trzeja trocha poczekać, to wszyscy ci lenini, troccy i cało ta bolszewicka pokaź pejsato pójdzie na gałąź"

„Cud nad Wisłą" zaowocował kontrakcją Górnoślązaków, co spotkało się z ostrą reakcją niemieckich mediów. Jak pisała „Gwiazdka Cieszyńska”: „prasa berlińska i wiedeńska przedstawiała wydarzenia na Górnym Śląsku jako nowe powstanie przygotowane dla przeprowadzenia aneksji tego obszaru polskiej ludności miejscowej w porozumieniu z rządem polskim. Cała prasa twierdzi, że napad Polaków

\footnotetext{
${ }^{68}$ K. Sosnkowski, Gen. Weygand o bitwie warszawskiej, „Wiadomości” [Londyn], nr 35 z 1 IX 1957.

${ }^{69}$ „Gwiazdka Cieszyńska”, nr 187 z 27 VIII 1920, s. 1.

${ }^{70}$ Tamże, s. 2.

${ }^{71}$ Tamże.
} 
dokonał się z namowy Francji w celu uniemożliwienia plebiscytu. Prawdą jest, że ludność polska, przy pomocy władz koalicyjnych zdołała uniemożliwić niemiecki zamach stanu" $"$.

Wybuchła kolejna insurekcja, której głównym celem była samoobrona. Południową część okręgu VII, podległą A. Dornowi, powstańcy śląscy opanowali już na przełomie 19 i 20 sierpnia 1920 r. Henryk Kalemba dowodząc 3 kompanią po zaciętej walce zdobył rodzinną miejscowość Józefowiec, łupem zwycięzcy padło 200 niemieckich karabinów. Następnie powstańcy z Józefowca wsparli 23 sierpnia natarcie na Wielkie Hajduki ${ }^{73}$. Inne grupy w powiecie katowickim zdobyły hutę „Baildon”, Nowy Bytom i Chorzów. Opór stawiały niemieckie posterunki w Siemianowicach i Bogucicach. Natomiast bez walki zajęto Giszowiec i Nikiszowiec. „Gwiazdka Cieszyńska” donosiła, iż: „Samoobrona powiatu bytomskiego tworzy się w całym powiecie. Bytom jest przez Polaków otoczony. Ruch samoobrony rozszerzył się dalej na powiaty pszczyński, tarnogórski, zabrzeski i rybnicki" $"$.

Na łamach „Gwiazdki Cieszyńskiej” redakcja komentowała bieg wydarzeń:

Położenie na Górnym Śląsku zdaje się poprawiać. Ponieważ Międzynarodowa Komisja Plebiscytowa przyjęła warunki robotników polskich co do usunięcia Sichereitswehry, więc ludność polska uspokoiła się i robotnicy powrócili do pracy. W Katowicach Sichereitswehra, albo jak mówią Polacy „sicherka” została ściągnięta do koszar, a porządku w mieście pilnują Francuzi i polska samoobrona powiatu katowickiego posunęła się pod same Katowice i otoczyła miasto ze wszystkich stron. Nikt nie może do miasta wejść, ani wyjść bez kontroli Polaków. „Sicherka” ma być zastąpiona przez straż obywatelską, z Polaków i Niemców pod komendą koalicyjną. Niemcy katowiccy pośpiesznie opuszczają miasto. W kilku miejscowościach „sicherka” została przez Polaków rozbrojona, przy czym dochodziło do krwawych walk. Tak było w Bogucicach pod Katowicami i w Mysłowicach. Polacy zażądali wydania broni i opuszczenia miasta. Gdy tego „sicherka” uczynić nie chciała, Polacy rozpoczęli oblężenie jej koszar. Po wyczerpaniu amunicji ,sicherka” się poddała, utraciwszy kilkunastu zabitych i rannych. Jeńców w ilości 100 osób odprowadzili Polacy do Sosnowca, gdzie ich władze polskie nie przyjęły lecz odesłały do rąk wojsk francuskich ${ }^{75}$.

72 „Gwiazdka Cieszyńska”, nr 186 z 24 VIII 1920, s. 2: „W Bogucicach walki trwały do 8 rano. Oddziały Sicherheitswehry musiały się cofnąć, po czym miejscowość znalazła się w rękach Francuzów. Obwołano przynależność do Polski. Służbę bezpieczeństwa objęli Francuzi i Polacy".

${ }^{73}$ Zob. Z. JANECZEK, Kpt. Henryk Aleksander Kalemba. Ofiara bezprawia i niechciany bohater, Siemianowice Śląskie 2019, s. 34.

${ }^{74}$ „Gwiazdka Cieszyńska”, nr 187 z 27 VIII 1920, s. 2. Samoobrona Górnego Śląka.

75 Tamże. 
W nocy z 25 na 26 sierpnia rozpoczęło się usuwanie Sicherheitswehry z Górnego Śląska; kolejno - z Zabrza, potem Bytomia, Katowic, Gliwic i innych miast. W środę wieczorem odbyło się w Bytomiu spotkanie przedstawicieli Polaków i Niemców w sprawie przywrócenia spokoju i porządku. „Gwiazdka Cieszyńska” pisała, iż jego inicjatorem była strona niemiecka. Polaków reprezentowali poseł Wojciech Korfanty i adwokat Konstanty Wolny. Niemcy wydelegowali charyzmatycznego centrowca księdza Carla Ulitzkę, zdecydowanego przeciwnika oderwania nawet najmniejszego skrawka Śląska od Republiki Weimarskiej, wiernego „matce Rzeszy”. Towarzyszył mu Żyd Bloch, który podzielał zdanie pruskiego duchownego ${ }^{76}$ i równocześnie starał się wcielić w życie oczekiwania berlińskiego „Wall Street”. Kontrolowało ono handel śląskim węglem, nie szczędząc w 1921 r. grosza na ochotników Freikorpsu i „Schwarz Reichswehry”, wśród których nie brakowało starozakonnych. Bloch reprezentował wyznawców judaizmu w większości wychowanych na Górnym Śląsku w kulturze niemieckiej, mocno z nią związanych, określających się jako „Niemcy wyznania mojżeszowego" i manifestujących swe przywiązanie do Rzeszy.

Pertraktacje nie należały do łatwych. W. Korfanty i K. Wolny oświadczyli, że przywrócenie spokoju możliwe jest tylko po wykonaniu warunków, które delegacje robotników polskich przedłożyły Komisji Rządzącej i które uzyskały jej akceptację. Najważniejszym z warunków było usunięcie Sicherheitswehry i zaprowadzenie „wspólnej milicji”, składającej się z 50\% Polaków i 50\% Niemców. Ostatecznie przedstawiciele niemieccy zgodzili się na polskie warunki i przedłożyli je do zatwierdzenia zgromadzeniu reprezentantów partii górnośląskich, które zostało zwołane do Gliwic.

Wkrótce na łamach „Gwiazdki Cieszyńskiej” ukazał się tekst zatytułowany Uspokojenie na Górnym Ślasku. Gazeta donosiła: „W plebiscytowych terytoriach Górnego Śląska nastąpił już spokój. Komisja Koalicyjna przystępuje do zastąpienia Sicherheitswehry przez policję lokalną, złożoną w połowie przez Polaków i Niemców. Komendantami tej policji będą oficerowie koalicyjni. Na 72 kopalń strajkuje jeszcze $6 .-80 \%$ górników podjęło pracę"77.

27 sierpnia 1920 r. został podpisany przez Walentego Fojkisa akt demobilizacji wszystkich oddziałów bojowych samoobrony ${ }^{78} .28$ sierpnia przedstawiciele polskiego i niemieckiego komitetu plebiscytowego wydali wspólną odezwę wzywającą do przywrócenia spokoju i podjęcia pracy. Uczestnicy drugiego powstania

\footnotetext{
76 „Gwiazdka Cieszyńska”, nr 188 z 31 VIII 1920, s. 2. Przed plebiscytem na Górnym Śląsku.

77 „Gwiazdka Cieszyńska”, 189 z 3 IX 1920, s. 2.

${ }^{78}$ CAW I 19051 ap. Korpus oficerów piechoty. Oficer rezerwy Kalemba Henryk. 73 Pułk Piechoty. Przebieg służby wojskowej w armii polskiej, k. 3.
} 
doprowadzili do usunięcia z obszaru objętego plebiscytem niemieckiej policji $\mathrm{SIPO}^{79}$, a także do rozwiązania niemieckich bojówek. Ponadto powstanie przybliżyło cel, jakim było przeprowadzenie plebiscytu. Jego ostateczny termin wyznaczono na 20 marca $1921 \mathrm{r}$.

Wypadki na Górnym Śląsku skutkowały ujawnieniem niemieckich dążeń. „Otworzyły także koalicji oczy na niezmniejszone jeszcze niebezpieczeństwo niemieckie. Mimo nakazu aliantów, Niemcy nie tylko, że nie oddały broni, ale zarządziły nowe zbrojenia, by opanować Górny Śląsk. Stwierdzono to urzędowymi dokumentami. Dokumenty te przedstawiono na konferencji w Spa"80. Rezultatem debat była decyzja o konieczności rozbrojenia Niemiec.

"Gwiazdka Cieszyńska” duże zasługi w tej batalii przypisywała Polskiemu Komisarzowi Plebiscytowemu. „Poseł Korfanty [...] ogłasza w «Oberschlesische Volkszeitung» oświadczenie oficjalne, że obecny ruch samoobrony Polski na Górnym Śląsku nie jest żadnym powstaniem przeciwko obecnej władzy, lecz tylko samoobroną przeciw gwałtom niemieckim. Polacy nie myślą podkopywać autorytetu koalicyjnej komisji rządzącej, ani też naruszać traktatu pokojowego co do plebiscytu górnośląskiego. Żądają tylko natychmiastowego usunięcia z Górnego Śląska Sicherheitswehry i wszystkich niespokojnych elementów z poza linii demarkacyjnej"81. Jako powód wyprowadzenia z Górnego Śląska tej formacji gazeta podała brak zaufania do Sicherheitswehry, którą rząd niemiecki zostawił ,jako swoje wojsko pod formą policji”. W cytowanej wypowiedzi W. Korfanty przytoczył wiele przykładów gwałtów niemieckich dokonanych na polskiej ludności, podczas których Sicherheitswehra zachowywała się biernie lub ,pomagała Niemcom, a nawet sama wywoływała rozruchy" $\$ 2$.

Podsumowania sierpniowych zmagań dokonał adwokat dr. Paweł Kempka, szef Wydziału Administracyjnego w Polskim Komisariacie Plebiscytowym w Bytomiu, na prośbę W. Korfantego delegat Polskiego Komisariatu Plebiscytowego w Warszawie. Opisał on przebieg drugiego powstania, 5 września br. na niedzielnym wiecu w sali Pod Jeleniem. Relację z tego spotkania zamieściła na swoich łamach „Gwiazdka Cieszyńska”. Redakcja komentując wypowiedź dr. P. Kempki, zakończyła artykuł apelem do czytelników: „Musimy nawiązać stosunki z Górnym Śląskiem i popie-

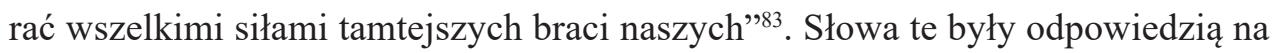
niemieckie zagrożenie.

\footnotetext{
79 „Gwiazdka Cieszyńska”, nr 177 z 8 VIII 1920, s. 3. Sicherheitswehr musi opuścić Śląsk Górny.

80 „Gwiazdka Cieszyńska”, nr 190 z 7 IX 1920, s. 3.

81 „Gwiazdka Cieszyńska”, nr 187 z 27 VIII 1920, s. 2.

${ }^{82}$ Tamże.

${ }^{83}$ „Gwiazdka Cieszyńska”, nr 190 z 7 IX 1920, s. 3.
} 
Niemcy zawiedzeni porażką Rosjan w bitwie Warszawskiej (13-25 sierpnia) i Nadniemeńskiej (20-26 września) oraz niepowodzeniem podjętej próby „,przewrotu” 17 sierpnia 1920 r., nie rezygnowali z dalszych usiłowań rozegrania kwestii Górnego Śląska zgodnie z interesem Republiki Weimarskiej. „Gwiazdka Cieszyńska” donosiła:

\begin{abstract}
W berlińskich kołach miarodajnych obawiają się, że koalicja podobnie jak to się stało w Cieszyńskiem, także w sprawie Górnego Śląska rozstrzygnie wyrokiem Rady Najwyższej bez przeprowadzenia plebiscytu i że w ten sposób, omijając traktat wersalski, odda obszary sporne Polsce. Zażegnanie konfliktu w obecnej chwili zdaje się być według opinii kół berlińskich możliwe tylko przez bezpośrednie rokowania przywódców ludności niemieckiej z generałem [Henri - Z.J.] Le Rond, gdyż interwencja rządu niemieckiego jest wykluczona ${ }^{84}$.
\end{abstract}

Jednak w dalszym ciągu trzeba było wystrzegać się prowokacji ze strony Berlina. Niemcy w ramach dezinformacji zaczęli rozpowszechniać na Górnym Śląsku fałszywe pogłoski, jakoby między 15 a 18 września miał wybuchnąć polski strajk generalny i nowe powstanie. W odpowiedzi Wojciech Korfanty, jako komisarz plebiscytowy, wystosował do mieszkańców Górnego Śląska odezwę, w której wyjaśniał, że pogłoski są nieprawdziwe i „pochodzą z tych samych prowokacyjnych czynników niemieckich, które wywołały krwawe wypadki w Katowicach dnia 17 i 18 sierpnia" $"$. Odezwa wzywała do zachowania spokoju i rozwagi. Natomiast „Gwiazdka Cieszyńska” alarmowała opinię publiczną zamieszczając w dziale Przeglad polityczny Polska artykuły: Hakata pruska dalej spiskuje na Górnym Śląku i List otwarty Korfantego do rzadu niemieckiego o rzekomym przygotowaniu nowego powstania ${ }^{86}$.

„Gwiazdka Cieszyńska”, rozpatrując problemy europejskie ze śląskiej perspektywy, snuła domysły i kierowała podejrzenia wobec zachodniego sąsiada Polski.

Na każdym kroku ma się tu wrażenie, że Niemcy swoje zamiary przeprowadzą - ostrzegała
gazeta. We wszystkich dziedzinach życia widać tu ogromną systematyczność i celową praco-
witość, a choć niektóre odłamy społeczeństwa wyjdą na chwilę z tego celowego dążenia do
lepszej przyszłości, jak socjaliści, którzy niekiedy zastrajkują, to prędko następuje opamię-
tanie i znowu życie gospodarcze, które jest podstawą powodzenia politycznego, idzie z ze-
garkową punktualnością. Niemcy podpisując traktat pokojowy miały na oku, że dotrzymają
go tak długo, aż wewnętrznie wzmocnione, wzrosną w siłę potrzebną do złamania wszyst-
kiego, co im nie na rękę. Nienawiść do aliantów duszą w sobie i knując zemstę, pracują nad
wewnętrznym odrodzeniem, a równocześnie oglądają się jakby aliantów rozdwoić, gotowi
połączyć się ze swym dzisiejszym największym wrogiem, byle tylko nasycić żądzę zemsty87.

84 „Gwiazdka Cieszyńska”, nr 187 z 27 VIII 1920, s. 2.

85 "Gwiazdka Cieszyńska”, nr 193 z 17 IX 1920, s. 2. Prowokacja niemiecka na Górnym Ślasku.

${ }^{86}$ „Gwiazdka Cieszyńska”, nr 195 z 24 IX 1920, s. 2.

87 „Gwiazdka Cieszyńska”, nr 187 z 27 VIII 1920, s. 2. 
Po odparciu wroga od „bram Warszawy”, w wyniku wygranej bitwy porównywalnej z bitwą nad Marną na przedpolach Paryża (15 lipca-5 sierpnia 1918) i zażegnaniu zagrożenia niemieckiego na Górnym Śląsku, „Gwiazdka Cieszyńska” podejmuje wysiłek wskazania rodakom dróg prowadzących do utrwalenia niepodległego bytu Rzeczypospolitej. ,Jeżeli chcesz przyczynić się jako prawy obywatel polski do zupełnego zwycięstwa oręża polskiego nad bolszewikami podpisz stosownie do swego majątku Pożyczkę Odrodzenia" "88. Zwraca się do czytelników ze wskazaniem: „Walkę z wrogami chrześcijaństwa wygramy tylko wtedy, jeżeli wrogów będziemy zwalczali tą samą bronią, której oni używali. Obóz wrogi stoi naprzeciwko nam w sile spojonych organizacji. Dlatego i my musimy stworzyć karne szeregi organizacji" ${ }^{89}$. Redakcja miała na myśli dobrą organizację społeczeństwa: polityczną (opartą na zasadach chrześcijańskich), zawodową i oświatową. Ponadto wskazywała, iż każdy człowiek, mężczyzna czy kobieta ma obowiązek troszczyć się o swoje państwo.

W imię tych wartości zredagowany został apel zaczynający się od słów:

Ludu śląski! Zapał najlepszych synów Ojczyzny, którzy wzbudzili podziw całego świata i rozsławili imię żołnierza polskiego, stworzył Cud Wisły. Potężna armia carskich generałów chciała pod osłoną szumnych haseł bolszewickich zagrabić naszą wolność i niepodległość, za którą umierali nasi dziadowie i ojcowie. Pewni zwycięstwa rozgłosili całemu światu upadek serca Polski, drogiej każdemu Warszawy. Na ratunek Ojczyzny pospieszył nasz polski lud, polski robotnik ze wszystkich krańców naszej Ojczyzny. Nie brakło tam także bohaterów z zachodnich kresów Polski. Na pierwszy odzew Naczelnika Państwa [Józefa Piłsudskiego - Z.J.] podążyli Ślązacy, by wpleść nowy liść do wieńca swej sławy. Ziemia piastowska, pokryta mogiłami obrońców tej najdroższej cząstki Rzeczypospolitej przed zakusami wrogów, zaznaczyła swoją łączność z Macierzą. Lecz wróg jeszcze nie pokonany, Ojczyzna potrzebuje nowych zastępów żołnierzy ochotników, by umocnić zwycięstwo i doprowadzić do upragnionego pokoju ${ }^{90}$.

\section{3. ŚLĄZACY!}

„Pokażcie swoim rodakom, że 600-letnia niewola nie znieczuliła waszych uczuć dla braci z innych dzielnic Polski. Głoście się tłumnie do szeregów. Wspomóżcie waszych braci, których gwałt jaki wam zadano, równie boli i którzy was nigdy

\footnotetext{
88 „Gwiazdka Cieszyńska”, nr 188 z 31 VIII 1920, s. 1.

${ }^{89}$ „Gwiazdka Cieszyńska”, nr 193 z 17 IX 1920, s. 2.

${ }^{90}$ Tamże.
} 
nie opuszczą w walce o złączenie rozdartych części Śląska. Porzućcie troski i zmartwienia. Losy krajów i narodów są zmienne. Po dniach rozpaczy i przygnębienia wstanie promienne słońce wyzwolenia naszych braci spod jarzma wroga"91. „Gwiazdka Cieszyńska” stawiała przed rodakami zadanie zwiększenia siły obronnej państwa wobec niemożności polegania na gwarancjach i pomocy sąsiadów (z wyjątkiem Węgrów) oraz państw Ententy. Gazeta reprezentowała pokolenie, które przeżyło katastrofę, jaką była pierwsza wojna światowa. Było ono doświadczone upokarzającymi gwałtami obcych wojsk. Jednak w Legionach Józefa Piłsudskiego poznało znaczenie słów: Wolność, Równość, Braterstwo, Niepodzielność i Niepodległość.

Ochotników, których wcielono do formującego się pułku śląskiego w Białej, przyjmowało biuro zaciągowe do pułku śląskiego przy baonie zapasowym 4 pułku strzelców podhalańskich w Cieszynie, przy ulicy Sztyftowej, i biuro zaciągowe w Bielsku Białej przy ulicy Franciszka Józefa 4. Zaciągiem kierowali major piechoty Edmund Bonifacy Żelawski (1876-1940) i major Bolesław Andrzej Ostrowski (1891-1964).

Grono Ślązaków, którzy wzięli udział w wojnie polsko-bolszewickiej, godnie reprezentowali m.in. Walenty Fojkis i Henryk Kalemba ${ }^{92}$, żołnierze 7 Pułku Piechoty Legionowej, którzy w $1921 \mathrm{r}$. zostali znanymi dowódcami w Trzecim Powstaniu Śląskim. W. Fojkis dowodził katowickim 1 Pułkiem im. Józefa Piłsudskiego, a H. Kalemba bił się pod sztandarem 3 Pułku Powstańczego im. gen. J.H. Dąbrowskiego, pod komendą Rudolfa Niemczyka. Dowodził baonem pod Górą św. Anny.

„Gwiazdka Cieszyńska” wciąż obok propagowania postaw patriotycznych, miała na uwadze poczynania zachodniego sąsiada. Między innymi opisywała Tajne konszachty bolszewicko-niemieckie w sprawie Gdańska ${ }^{93}$ i Górnego Śląska ${ }^{94}$, a przy okazji nawoływała, aby Warszawa ,przemówiła” w sprawie strajku dzieci polskich „pod czeskim zaborem”95.

Akcja plebiscytowa na Górnym Śląsku obfitowała w liczne spory i napięcia łącznie z utarczkami z niemieckimi bojówkami Selbstschutzu ${ }^{96}$. "Gwiazdka Cieszyńska” pisała o „napadach na Polskę” ze strony księdza Carla Ulitzki. Szerszy komentarz

91 Tamże.

92 Z. JANECZEK, Kpt. Henryk Aleksander Kalemba. Ofiara bezprawia i niechciany bohater. Siemianowice Śl. 2019, s. 25-30.

93 „Gwiazdka Cieszyńska”, nr 198 z 8 X 1920, s. 2.

94 „Gwiazdka Cieszyńska”, nr 203 z 22 X 1920, s. 2.

95 „Gwiazdka Cieszyńska”, nr 202 z 19 X 1920, s. 3.

96 „Gwiazdka Cieszyńska”, nr 196 z 28 IX 1920, s. 2. Plebiscyt na Górnym Śląsku; zob. tamże nr 221 z 24 XII 1920, s. 1-2. Górny Śląsk. Protesty przeciw emigrantom i Górnoślązaku! Plebiscyt odbędzie się wkrótce. 
na ten temat wyrażał artykuł pt. Niemieckie gwatty na Górnym Ślask $k u^{97}$. Spór zaostrzył się, gdy doszło do niekorzystnej interpretacji wyników plebiscytu. Polacy oczekiwali, że zgodnie z aneksem do art. 88 traktatu wersalskiego głosy będą zliczane nie globalnie, a gminami, których za Polską głosowało 44,7\%, jednakże wbrew ustaleniom, w Komisji Międzysojuszniczej przewagę zaczęła zdobywać koncepcja brytyjsko-włoska oparta na globalnym liczeniu głosów i przyznająca Polsce tylko $25 \%$ obszaru plebiscytowego, tj. powiaty pszczyński, rybnicki i przylegające do nich lub polskiej granicy skrawki powiatów: raciborskiego, toszecko-gliwickiego, katowickiego, bytomskiego, tarnogórskiego i oleskiego. Wytyczona granica podziału nazwana od nazwisk komisarzy Anglii i Włoch - linią Percivala-de Marinisa nie zadowalała żadnej ze stron. 5 maja 1921 r. na posiedzeniu Rady Ambasadorów miała się odbyć dyskusja nad ostatecznym rozstrzygnięciem, z uwzględnieniem korzystniejszej dla Polski koncepcji gen. Henri Le Ronda (1864-1949). Wiadomo już jednak było, że z powodu stanowiska Anglii i Włoch zapadnie dla Polski krzywdzące postanowienie.

Tak więc w kręgach konspiratorów wojskowych POW G.Śl. podjęto ostateczną decyzję o rozpoczęciu trzeciego powstania. Naczelny wódz Maciej Mielżyński zanotowat:

1 maja 1921 roku odebrałem od rządu kategoryczny zakaz rozpoczynania jakiejkolwiek akcji zbrojnej na Górnym Śląsku, pod osobistą odpowiedzialnością. Tego zakazu nie usłuchałem. Wiedziałem, że jedynie akcja zbrojna, rozpoczęta natychmiast, może sytuację uratować. Niewątpliwym było, że rząd polski miał związane ręce i działał pod presją mocarstw sprzymierzonych, z głębi duszy zaś życzyć musiał, żeby nasi bracia Górnoślązacy osiągnęli zwycięstwo nad Niemcami. Zwłaszcza że Niemcy, choć urzędowo głosili, że nie mieszają się do walki na terenie plebiscytowym, to całe pułki z Niemiec przez granice puszczali na Górny Śląsk ${ }^{98}$.

Z kolei Wojciech Korfanty, nie chcąc narażać rządu RP na posądzenie o wywołanie powstania, złożył urząd Polskiego Komisarza Plebiscytowego i ogłosił się dyktatorem. Już wcześniej Prusacy oskarżali go, iż podburza Polaków przeciw Niemcom, co znalazło odzwierciedlenie w artykule pt. Niemcy a Korfanty, opublikowanym na łamach „Gwiazdki Cieszyńskiej”"99.

W tej trudnej sytuacji Józef Piłsudski dotrzymał danego Górnoślązakom słowa i wysłał z pomocą „,co miał najlepszego”, blisko 5000 ludzi, m.in. byłych legionistów,

97 „Gwiazdka Cieszyńska”, nr 217 z 10 XII 1920, s. 2.

${ }^{98}$ M. MielżYŃSKI, Wspomnienia i przyczynki, s. 74-75.

99 „Gwiazdka Cieszyńska”, nr 215 z 3 XII 1920, s. 2. 
bojowców PPS i Peowiaków oraz ponad 60 tys. karabinów. Wśród ochotników znaleźli się zbuntowani kadeci lwowscy i por. Jan Kowalewski ${ }^{100}$. Ten ostatni nieprzypadkowo pokierował wywiadem w trzecim powstaniu śląskim. Miał, jako kryptolog, za sobą w tej dziedzinie znaczące dokonania. W czasie Bitwy Warszawskiej w sierpniu $1920 \mathrm{r}$. informacje polskiego radiowywiadu zorganizowanego przez Jana Kowalewskiego miały „bezwzględnie rozstrzygający wpływ” na decyzje strategiczne Józefa Piłsudskiego i w konsekwencji na rozmiar zwycięstwa Wojska Polskiego nad nacierającą na Warszawę Armią Czerwoną, czego pokłosiem było drugie powstanie śląskie. Kowalewskiemu towarzyszyli na Górnym Śląsku inni oficerowie II Oddziału, m.in. por. Edmund Kalikst Charaszkiewicz ${ }^{101}$. Wszyscy oni zdążyli na czas do wyznaczonych miejsc, by podjąć się realizacji swojej misji. W nocy z 2 na 3 maja wybuchło trzecie powstanie śląskie.

Wszystkie zawiłości dziejów Górnego Śląska tego okresu oddał znawca realiów tej ziemi, jego mieszkańców i ich mentalności Gustaw Morcinek, w znakomitej powieści, prezentującej walory dokumentalne, Mat Kurt Kraus, na której łamach obok Wojciecha Korfantego, Arki Bożka występują bohaterowie Grupy „Wawelberga” na czele z Tadeuszem Puszczyńskim ${ }^{102}$, żołnierzem 4 batalionu I Brygady Legionów Polskich. To oni już w pierwszych godzinach powstania znacząco przyczynili się do jego sukcesu.

\section{ZAKOŃCZENIE}

Powodzenie militarne bitwy warszawskiej i trzeciego powstania śląskiego skutkowało włączeniem w granice II Rzeczypospolitej wschodniej części Górnego Śląska, która była drugim zagłębiem przemysłowym Europy. Wydarzenie to zmieniło w znaczący sposób strukturę gospodarczą rolniczej Polski, upodobniając stosunki polskie do krajów o kulturze kapitalistycznej. Przyłączenie części tej historycznej prowincji, którą Jan Długosz zaliczał do części „ciała Korony Polskiej”,

\footnotetext{
${ }^{100}$ Jan Kowalewski (1892-1965), w latach 1909-1913 studiował na Uniwersytecie w Liège, otrzymując dyplom z chemii technicznej. Znał kilka języków obcych, m.in. niemiecki, francuski i rosyjski; podpułkownik dyplomowany piechoty WP, matematyk, lingwista i kryptolog, który złamał sowieckie szyfry w czasie wojny z bolszewikami, wieloletni oficer Oddziału II Sztabu Głównego. Za udział w trzecim Powstaniu Śląskim otrzymał Srebrny Krzyż Virtuti Militari.

${ }^{101}$ Edmund Kalikst Charaszkiewicz (1895-1975), uczestnik wojny polsko-bolszewickiej oraz ochotniczo Trzeciego Powstania Śląskiego; podpułkownik piechoty WP, oficer Oddziału II Sztabu Generalnego WP. Zmarł w Londynie.

${ }^{102}$ Gustaw Morcinek. W 120-lecie urodzin. 03 „,Mat Kurt Kraus” powieść o powstaniach ślaskich, red. K. Heska-Kwaśniewicz i J. Leszczyna, Katowice 2012, s. 34-37.
} 
ze względu na wielkość potencjału przemysłowego i wojskowego tego obszaru było dużym wydarzeniem nie tylko politycznym, ale i gospodarczym, a także wojskowym. Górny Śląsk był największym okręgiem przemysłowym w kraju. Fakt ten podkreślała „Gwiazdka Cieszyńska” w artykule $O$ znaczeniu Górnego Śląska ${ }^{103}$. W roku 1923 miejscowe kopalnie i huty dostarczały 73\% stali, 87,7\% cynku i $99,7 \%$ ołowiu. Bez tej produkcji niemożliwa była odbudowa i rozwój gospodarki polskiej po pierwszej wojnie światowej. Działało w tym obszarze ponad 1500 zakładów, z których wiele miało kluczowe znaczenie dla obronności Polski ${ }^{104}$. Nieprzypadkowo Józef Piłsudski, któremu przypisywano zwycięstwo w bitwie warszawskiej, i tzw. cud nad Wisłą, 27 sierpnia 1922 r. po odebraniu defilady, wysłuchaniu Mszy św. i dekoracji powstańców śląskich Krzyżami Virtuti Militari na katowickim Rynku, powrót Śląska do Macierzy nazwał „cudem nad Odrą”.

Z kolei wielki syn śląskiej ziemi, Prymas Polski August Hlond wpisał umiejętnie „cud nad Wisłą” i „cud nad Odrą” w dzieje ogólnonarodowych zmagań w obronie cywilizacji chrześcijańskiej i szeroko pojętej idei wolności. Podobnie jak bitwę pod Grunwaldem - odsiecz wiedeńską Hlond zaliczał do wydarzeń historycznych, których pamięć ukształtowała święta narodowe, usuwające w cień spory, jednoczące społeczność polską w kraju i za granicą. Zwycięstwo pod Wiedniem było „koniecznością dziejową" i wyrosło „z wyższości ducha polskiego, spotęgowanego pięciowiekowym bojowaniem o wiarę i cywilizację”. Hlond nauczał, iż szło ono „od pól legnickich, poprzez Warnę, Cecorę, Chocim. Dojrzewało w bojach i wyprawach bez liku. Było finałem wielkiego zmagania się z naporem zbrojnym półksiężyca" ${ }^{105}$. W rozważaniach tych głównym bohaterem odsieczy pozostawał Jan III Sobieski, który prowadził, „żelazne rycerstwo polskie i barwne armie sprzymierzone do zwycięstwa, które z istoty swej było triumfem Krzyża i kultury europejskiej”106. W podobnym duchu rozpatrywał ,cud nad Wisłą”, gdy w 1920 r. zbrojne ,hufce bezbożnego materializmu” stanęły pod murami Warszawy i ,zażąałały wolnej drogi do Europy”. Tym razem do walki Polacy musieli stanąć osamotnieni. Dlatego Hlond znacznie wyżej ocenił ten czyn zbrojny w porównaniu z 1683 r. „Stawka większa była niż pod Wiedniem. Trud wojenny niezrównany”107. Rozgromienie „potęgi orężnej

\footnotetext{
${ }^{103}$ „Gwiazdka Cieszyńska”, nr 215 z 3 XII 1920, s. 4.

${ }^{104}$ K. PINDEL, Miejsce Górnego Ślaska w systemie obronnym Drugiej Rzeczypospolitej, w: Rola i miejsce Górnego Śląska w Drugiej Rzeczypospolitej, red. W.W. Wanatowicz, Bytom-Katowice 1992, s. 113.

${ }^{105}$ Hasło Triumfów, Poznań, dnia 5 VIII 1933, „Ruch Katolicki”, nr 9-10 z 1933.

${ }^{106}$ Hasto Triumfów, Poznań, dnia 5 VIII 1933, „Ruch Katolicki”, nr 9-10 z 1933. Zob. Przemówienie na uroczystościach wiedeńskich. Wiedeń, dnia 12 IX 1933, „Die Reichspost”, nr 256 z 12 IX 1933.

${ }^{107}$ Hasto Triumfów, Poznań, dnia 5 VIII 1933, „Ruch Katolicki”, nr 9-10 z 1933.
} 
wschodu" było zdaniem Prymasa możliwe tylko dzięki instynktowi dziejowemu Polaków i głębokiej wierze Chrystusowej. „Ratując raz jeszcze wiarę i kulturę europejską, Polska przysądziła sobie dawne tytuły chwały, a zwycięską krwią przypieczętowała swoje niezstarzałe prawa do bytu i posłannictwa"108. Wiedeń i Warszawa w historii symbolizowały niezwyciężone twierdze Zachodu ${ }^{109}$.

\section{BIBLIOGRAFIA}

\section{ŹRÓDŁA ARCHIWALNE}

Centralne Archiwum Wojskowe w Warszawie: I 19051 ap. Korpus oficerów piechoty. Oficer rezerwy

Kalemba Henryk. 73 Pułk Piechoty. Przebieg służby wojskowej w armii polskiej, k. 1- 3.

Biblioteka Śląska w Katowicach. Dział Zbiorów Specjalnych

Powstania Śląskie. Dokumenty Instytutu im. Józefa Piłsudskiego w Nowym Jorku.

NKWP - historie, kroniki i organizacja różnych oddziałów, dziennik Głównego Dowództwa Etapów Górnego Śląska, mapy i szkice. Nr zespołu 008, sygn. 205. Sygn. dawna A. XIII T. XIII/360.

NKWP - meldunki sytuacyjne, rozkazy, korespondencja 1921 r. Nr zespołu 008, sygn. 209. Sygn. dawna A. XII T. XII/358 b.

\section{ŹRÓDŁA DRUKOWANE}

Archiwum Powstań Śląskich. Okres pierwszego powstania 1919 roku, seria I, t. I, oprac. E. Długajczyk, P. Parys, Wyd. Muzeum Śląskie w Katowicach 2017.

BACZyŃski S., Tajne organizacje wojskowe na Górnym Ślasku w latach 1918-1921 na tle sytuacji ogólnej, „Najnowsze Dzieje Polski 1914-1939”, 13(1968), s. 113-156.

Benisz A., Górny Ślask w walce o polskość. Katowice 1930.

Borth W., Z walk o niepodległość na Górnym Śląsu, Katowice 1938.

Brandys J., Walki powstańcze na Górnym Ślasku, „Przegląd Zachodni” [Londyn], 1958, nr 10-11.

Charaszkiewicz E., Rola dywersji w III powstaniu górnoślaskim, „Dziennik Polski” [Londyn], nr 103 z 1 V 1971.

Chmielewski M., Argumenty pisane krwia, „Strażnica Zachodnia”, 1931, nr 3.

DĄBRowski W., Trzecie powstanie śląskie, Londyn 1973.

DĄBRowsKi W., Górny Śląsk w walce o zjednoczenie z Polską. Źródła i dokumenty z lat 1918-1922, Katowice 1923.

Gawrych J.A., Hotel „Lomnitz”. Z tajemnic szefa wywiadu, Katowice 1947.

GaWrych J.A., Nie bytoby plebiscytu, Katowice 1936.

GrAŻYŃSKi M., Powstania śląskie, „Powstaniec Śląski”, 1935, nr 5.

\footnotetext{
${ }^{108}$ Tamże.

${ }^{109}$ Odezwa do Wiednia z okazji 250-lecia odsieczy wiedeńskiej. Poznań, dnia 26 VIII 1933, „Przewodnik Katolicki”, nr 36 z 1933, s. 574.
} 
GrAŻYŃSKi M., The Odra - Nysa. A frontier of Central Eastern European Federation and a guarantee of lasting peace, London 1952.

HoroszKiewicz R., W trzecim powstaniu ślaskim, Warszawa 1936.

Keller J., Gliwice - Katowice - Kędzierzyn, w: Pamiętniki powstańców śląskich, t. I, red. T. Karczewski, F. Szymiczek, R. Pitera-Ratepi, Katowice 1957.

LudyGa-Laskowski J., Materiaty do historii powstań G/ślaskich 1919-1920, t. I, Katowice 1925.

LuDYGA-LASKOwsKi J., Zarys historii trzech powstań śląskich górnośląskich 1919, 1920, 1921, Warszawa-Wrocław 1973.

MiElżYŃSKI M., Wspomnienia i przyczynki do historii III powstania górnośląskiego, Mikołów 1931.

NiEMcZYK R., Wspomnienia walk z czasów zdobywania i okupowania miasta Katowic podczas III powstania przez 3 Pułk imienia Dąbrowskiego-Niemczyka, „Powstaniec Śląski”, 1936, nr 5.

NIEMCZYK R., Działalność 3 PP w III powstaniu ślaskim, w: O wolność Śląska, Katowice 1931.

O wolność Śląska. W dziesięciolecie III powstania 1921-1931. Pamiętnik wydany przez Komitet uroczystości, Katowice 1931.

Piechoczek L., Powiat rybnicki w czasie powstań śląskich, Rybnik 1934.

Rostworowski S., Kadra oficerska w III powstaniu górnoślaskim 1921, „Polska Zbrojna”, nr 147 z 29 V 1935 i 148 z 30 V 1935.

Rostworowski S., Tajna Organizacja Wojskowa Obrony Plebiscytu na Górnym Ślasku w 1921 r., „Bellona”, 37(1931), nr 1-3.

Rostworowski S., Taktyczny przebieg trzeciego powstania górnośląskiego, „Bellona”, 8(1922), z. 2. Wyglenda J., Plebiscyt i powstania śląskie, Opole 1966.

PRASA

„Gwiazdka Cieszyńska” 1920-1921

\section{OPRACOWANIA}

ANusiewicz M., WrzoseK M., Kronika powstań ślaskich 1919-1921, Warszawa 1980.

CYGAŃSKi M., Struktura i antypolska działalność niemieckiego wywiadu na Śląsu (1920-1932), „Studia Śląskie", 37(1980), s. 41-63.

DŁugajCZYK E., Górny Śląsk po powstaniach i plebiscycie, Katowice 1977.

DŁugajCzyK E., Wywiad polski na Górnym Śląsu 1919-1922, Katowice 2001.

DŁugajczyK E., Polska konspiracja wojskowa na Śląsku Cieszyńskim w latach 1919-1920, Katowice 2005.

DobrzycKi W., Powstania ślaskie, Warszawa 1971.

Grygier S. i Grygier S., Kontakty polityczne i wojskowe Wielkopolski i Ślaska w latach 1919-1921, w: Wielkopolska a powstania śląskie 1919-1921, red. B. Polak, Leszno 1977, s. 13-56.

JANECZEK Z., Zapomniany dowódca. Jan Emil Stanek. (1895-1961), Siemianowice Śląskie 2007.

JANECZeK Z., Poczet dowódców powstań śląskich, Katowice 2008.

JęDruszCZAK T., W sprawie drugiego powstania ślaskiego, „Kwartalnik Historyczny”, 1955, nr 4-5. JęDruszczak J., Polityka Polski w sprawie Górnego Śląska 1918-1922, Warszawa 1958.

JęDruszczak J., Powstania śląskie 1919-1920-1921, Katowice 1964.

Karuga W., Organizacja Polskiego Komisariatu Plebiscytowego dla Górnego Śląska, Opole 1966. 
Katsch H., Der Oberschschlesische Selbstschutz im dritten Polenaufstande, Berlin 1921.

Kryska-Karski T., Żurakowski S., Generałowie Polski Niepodległej, Londyn 1976.

ŁĄCZEwski J., Mieczysław Chmielewski - działacz ruchu niepodległościowego, powstaniec ślaski, „Studia Śląskie”, 38(1981).

NowAK A., Niepodległa! 1864-1924. Jak Polacy odzyskali ojczyznę, Kraków 2018.

NowaK A., Pierwsza zdrada Zachodu. 1920 - zapomniany appeasement, Kraków 2015.

PACHOŃSKI J., Kraków wobec powstań ślaskich i plebiscytu, Warszawa-Kraków 1981.

PePloński A., Oddział II Sztabu Generalnego NDWP. Zarys organizacji i działalności (1919-1920),

„Wojskowy Przegląd Historyczny”, 1994, nr 1-2, s. 88-103.

Przewıocki J., Historiografia Polska o III powstaniu ślaskim, „Śląski Kwartalnik Historyczny Sobótka", 27(1972), nr 1.

Przewıocki J., Międzysojusznicza Komisja Rządzaca i Plebiscytowa na Górnym Śląsu w latach 1920-1922, Wrocław-Warszawa 1970.

Przewıocki J., Wokót II powstania śląskiego, „Zaranie Śląskie”, 1970, nr 2.

PrZewŁocki J., Mocarstwa zachodnioeuropejskie wobec problemów Górnego Śląska w latach 19181939, Warszawa-Kraków 1978.

PrZYBYLSKi A., Wojna polska 1918-1921, Warszawa 1930.

RęGOROwicz L., Górny Ślask w czasie plebiscytu i III powstania, Katowice 1961.

RyżEwski W., Powstania śląskie 1919-1921, Warszawa 1966.

RYŻEwski W., Zaangażowanie Rzeczypospolitej w ruch powstańczy na Górnym Śląsku. Uwarunkowania i postulaty, w: Powstania śląskie i plebiscyt w procesie zrastania się Górnego Śląska z macierza, Bytom 1993.

WrzoseK M., Powstania śląskie 1919-1921, Warszawa 1971.

Zaolzie. Polsko-czeski spór o Ślask Cieszyński 1918-2008, red. G. Gąsior, Warszawa 2008.

ZARZYCKa Z., Polskie działania specjalne na Górnym Śląskim 1919-1921, Warszawa 1989.

ZIELIŃSKI W., Polska i niemiecka propaganda plebiscytowa na Górnym Śląsku, Wrocław-Warszawa 1972.

ZIELIŃSKI W., Ludzie i sprawy hotelu „Lomnitz”, Katowice 1985.

\section{UPPER SILESIA AND THE POLISH-BLOSHEVIK WAR IN GWIAZDKA CIESZYŃSKA}

\section{REPORTS AND OPINIONS}

Abstract. Based in the analysis of press materials, mainly from Gwiazdka Cieszyńska (The Cieszyn Starlet), from 1920-1921, the article presents the links between Upper Silesia and the Republic during the Polish-Bolshevik war, especially in the summer of 1920, when the battle of Warsaw took place. The outcome of "the Miracle of the Vistula" was "the Miracle of the Oder".

The military success of the battle of Warsaw and the third Silesia uprising resulted in the incorporation of Upper Silesia, the second most industrialized region in Europe, into the Republic. The event significantly changed the economic structure of agricultural Poland, making it more similar to capitalist states. Due to its industrial and military potential, incorporating this historical region, which Jan Długosz counted among the parts of "the body of the Polish Crown," was an important political, 
economic, and military event. Upper Silesia was the biggest industrial region in the country. This fact was emphasized by Gwiazdka Cieszyńska in the article O znaczeniu Górnego Ślaska ("On the importance of Upper Silesia") published in issue 215 from 1920.

Keywords: Silesia uprising; Polish-Bolshevik war; "Warschau gefallen"; "miracle of the Vistula"; "miracle of the Oder"; plebiscite; Upper Silesia; treaty of Versailles; appeasement; Sicherheitswehr.

Translated by Hubert Kowalewski 